\title{
Review on Identification of Diterpenoid Resins in Artworks Varnishes by FTIR
}

\author{
Ali Nemati-Babaylou ${ }^{{ }^{1}}$, Mehrnaz Azad-Boyaghchi ${ }^{2}$, Farhood Najafi ${ }^{3}$, Mohsen \\ Mohammadi-Achachlouei ${ }^{4}$ \\ ${ }^{1} \mathrm{PhD}$ candidate, Faculty of Conservation-Restoration, Art University of Isfahan, IRAN \\ ${ }^{2,4}$ Assistant Professor, Faculty of Conservation, Art University of Isfahan, Isfahan, IRAN \\ ${ }^{3}$ Assistant Professor, Department of Resin and Additives, Institute for Color Science and Technology, \\ Tehran, IRAN
}

\begin{abstract}
Making varnishes from diterpenoid resins with the several orders had been common in Iran from 12th Century and it has also been reported in Europe from medieval ages. Identification of these resins in old samples and investigation of their degradations through ageing process have performed by various methods. FTIR spectrometry has always been of interest to researchers because it is cheap, available and it requires little sample material. Ditepenoid resins are classified into two classes: mixture of abietane and pimarane structures resins that include colophony and venetian turpentine, and resins that are formed from labdane and pimarane structures which involve sandarac and copal types. Abietane structures do not polymerized in the time but labdanes and pimaranes polymeriz at a very short time. For this reason, they mostly are used in oil-resin varnishes. These characteristics have led the two classes of resins to operate differently during ageing process and production of degradation products. This differentiation helps to identify to characterize the original structure of resin in the varnish compound in FTIR spectrometry. This article reviews the identification characteristics of diterpenoid resins in FTIR spectrometry and it tries to investigate and introduce every resin characteristics according to their structure from several references. Moreover, identification characteristics of linseed oil is introduced because of its application in oil-resin varnishes. Also, degradation process and its production are also reviewed. Differentiation in chemical structures of diterpenoid resins causes the differentiation of ageing process such the polymerisation of labdanes and pimaranes and cross linking in ageing process produce some new functional groups. Also some functional groups are destroyed during ageing. The changes observed in FTIR spectrometry are inclined oxidation and polymerization of varnishes that in turn changes bands intensity related to $\mathrm{OH}$ region, especially in 3000 and $3450 \mathrm{~cm}-1$ and carbonyl region bands. Degradation process of resins in solvent and oil-resin varnishes is same but identification of resin characteristics in oil-resin varnishes is difficult because of effects of oil oxidation on varnish spectra after aging process. Also cross links in varnish structure during aging process cause the formation of some new bands in aged varnishes spectra. Degradation products in resinits and ambers are to some extent like that of old resins and varnishes because their aging process is same.
\end{abstract}

Keywords: Diterpenoid resins, FTIR Spectrometry, Sandarac, Copal, Colophony, Linseed oil.

*Corresponding author: a.n.babaylou@gmail.com 


\section{يثوهن}

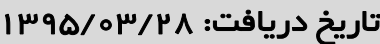

مقاله مرورى

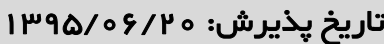

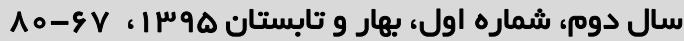

\section{مرورى بر شناسايى رزينهاى دى ترينوييد در ورنى آثار هنرى به روش طيفسنجى مادون قرمز تبديل فوريه

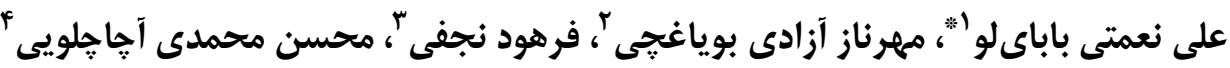

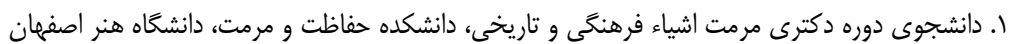

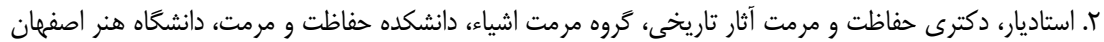

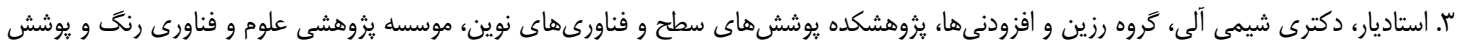

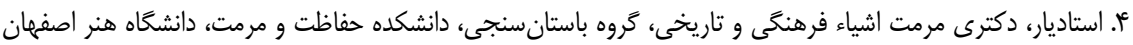

جکكيده

استفاده از رزينهاى دى إينوييد حداقل از قرن ششم هجرى در ايران و از قرون ميانه در ارويا جهت ساخت ورنى گَزارش شـاه و درد

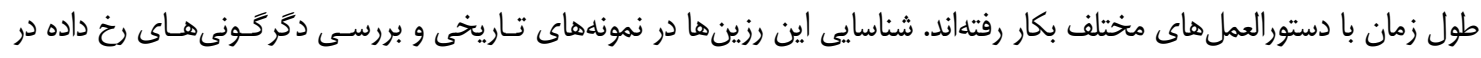

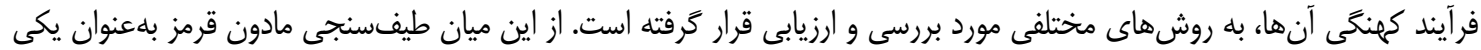

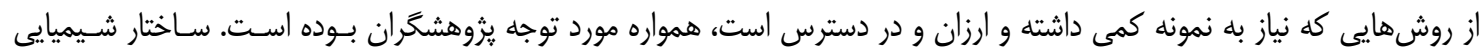

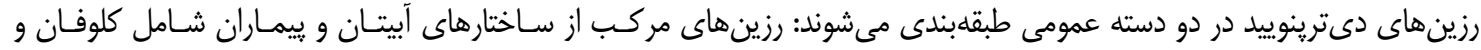

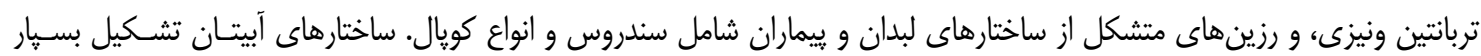

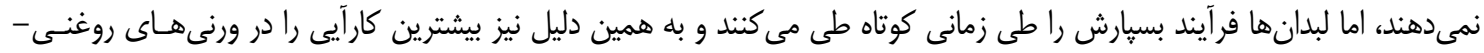

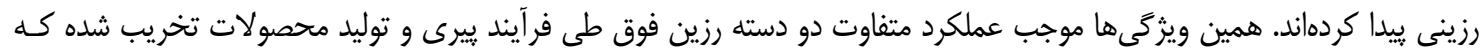

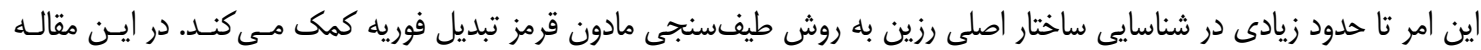

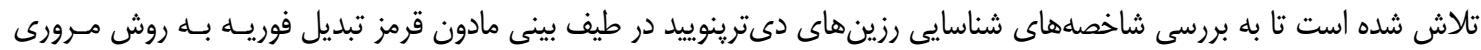

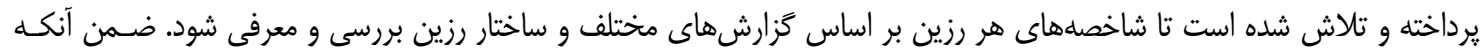

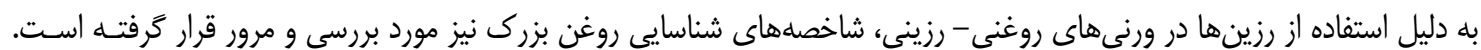

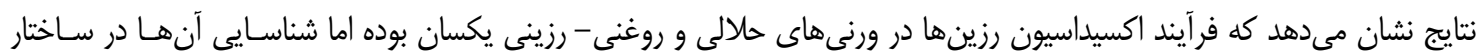

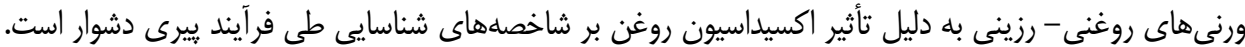
وازكان كليدى: رزينهاى دىترينوييد، طيفسنجى مادون قرمز، سندروس، كويال، كلوفان، روغن بزركى

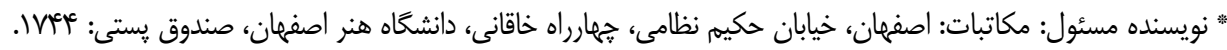

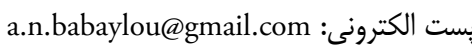

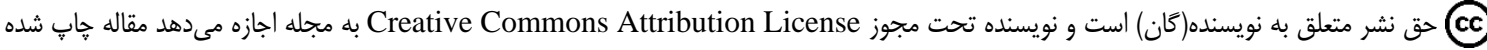
را با ديخران به اشتراك بكذارد منوط بر اينكه حقوق مؤلف اثر حفظ و و به انتشار اوليه مقاله در اين مجله اشاره شود. 
تركيب روشهـاى فـوق بـهـ نتـايج مـوفقى در شناسـايى

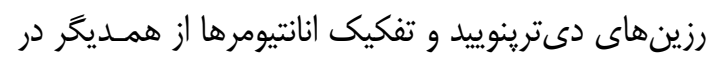

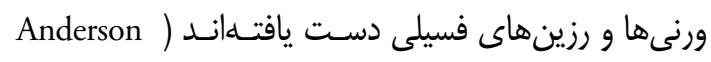
طيـف (and Crelling, 1995; Scalarone et al., 2003 مادون قرمز يك رزين تحت تأثير عوامل مختلفى جـون

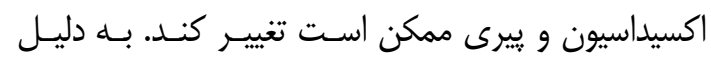

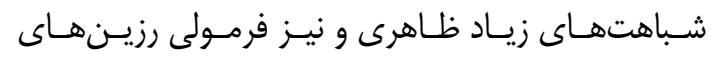

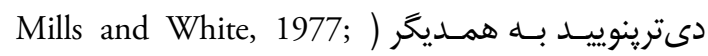

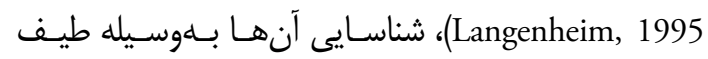

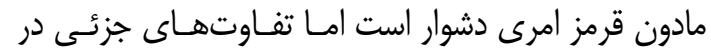

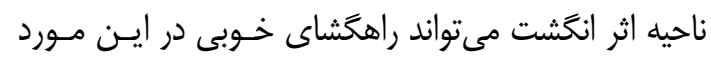

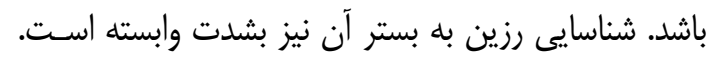
در ورنىهاى حلالى رزين در داخل يك حلال حل شده و هِ از تبخير حلال تشكيل فيلم مى دهد. بنابراين تغييرات

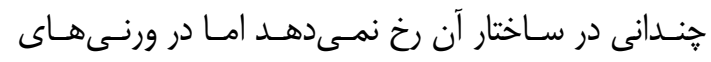
روغنى - رزينى، رزين در حرارت بالا در داخل يكى روغـن

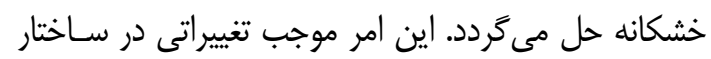

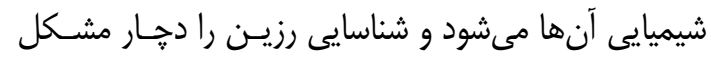

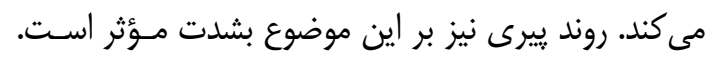

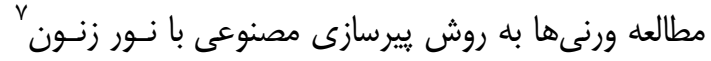

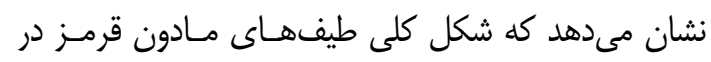

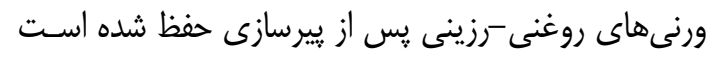

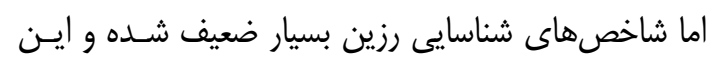

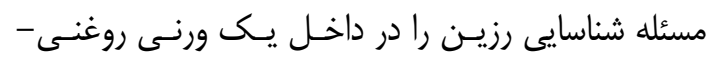
رزينى بيجِيدهتر مى كند ( Azemard et al., 2014, Ciofini

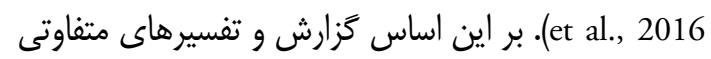

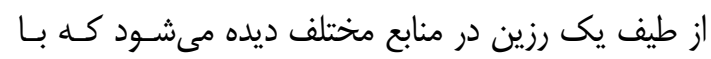

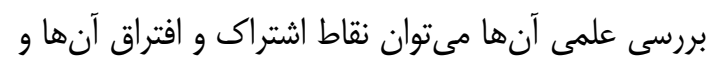

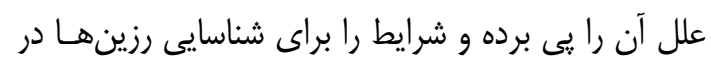

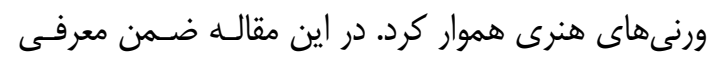

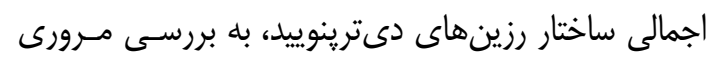
مطالعات انجام شده به روش طيـفســنجى مـادون قرمـز

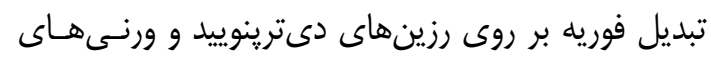

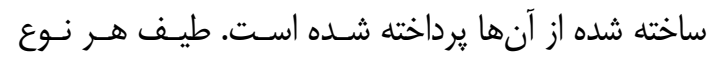

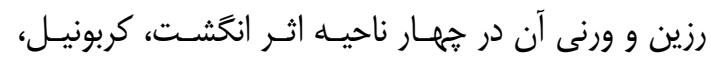
هيدروكسيل و ناحيـه CH مــورد بررسـى و تحليـل قـرار

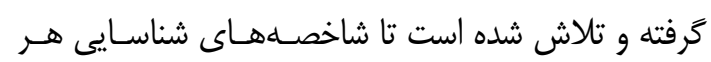

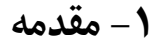

مواد رزينى هيجزَنه ريختشناسى مشخصى ندارند و تنها

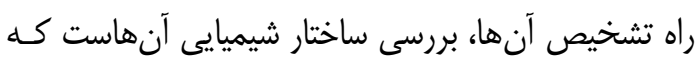

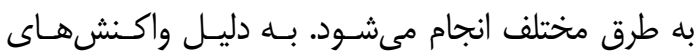
مختلف و رفتار ييرى تركيبات سازنده رزينهـا، شناسـايى رزينهاى طبيعى در ورنىها مشكل است. كذشت زمان بر كميت و كيفيت رزينهاى طبيعى تأثير گذاشـته و سـاختار

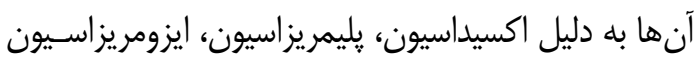

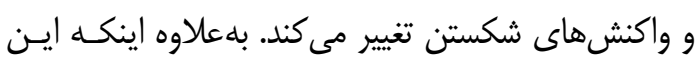

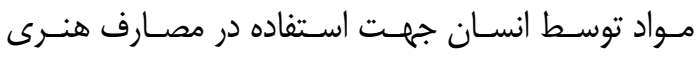
دستخوش تغيير شده و برهم كنش آنهــا بـا سـاير مـواد

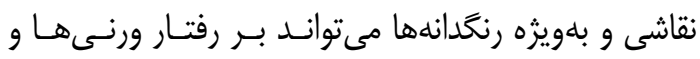

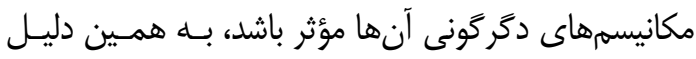
روش آناليز و شناخت اين گَونه مواد همواره مورد مناقشه و و

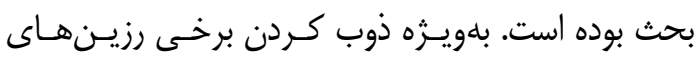
دى ترينوييد در مواد روغنى براى ساخت ورنىها در دمـاى

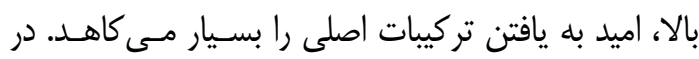

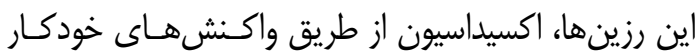

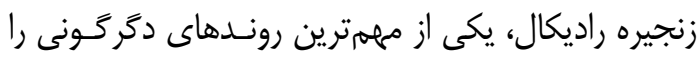

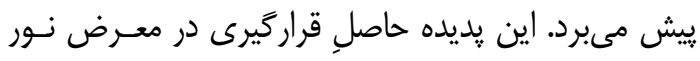

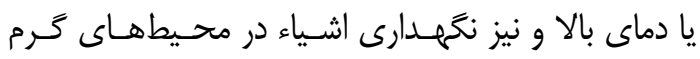

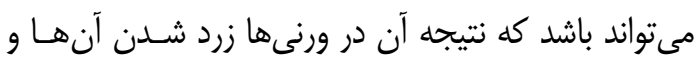

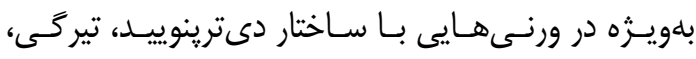

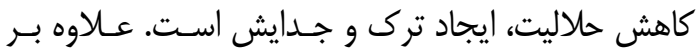

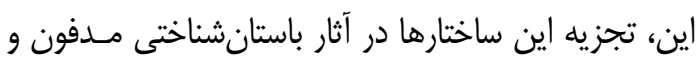

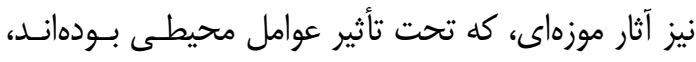

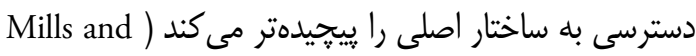
(White, 1977; Ribechini, 2009 عمدهاى از شاخصههاى رزينها در ورنسىهاى حلالى و

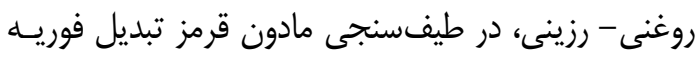

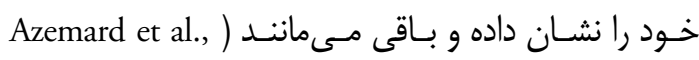

.(2014; Daher et al., 2010; Ciofini et al., 2016 در سه دهه اخير محققـان بـا اسـتفاده از روشهـاى مختلفى جـون طيـف بينـى تبـديل فوريـه مـادون قرمـز 'و و رامان '، طيف بينـى جرمسى (FTIR)

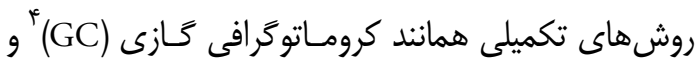

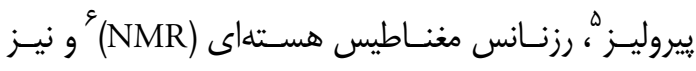




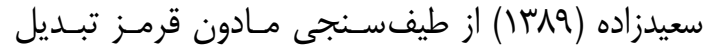
فوريه براى تشخيص شـاك از روغـنـ كمــان اسـتفاده

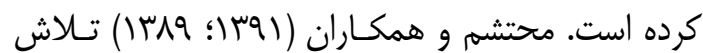
كردهاند تا كاربرد روغن كمان راد مر مطلاكارى تزيينـات ديوارى كاخهاى قاجارى تهران با استفاده از طيفسنجى مادون قرمز تبديل فوريه اثبات كنــــ و نتـايج خـود را بـانـا

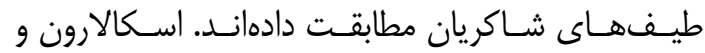
همكارانش به بررسى ساختار مواد در سندروس و كويـال دادئل

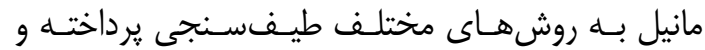
محصولات تخريب آنها در اثر نور را نيز مـورد بررسى مانى

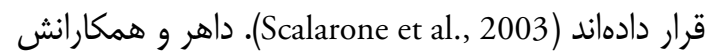
بستهاى آلى بكار رفته در نقاشى و ورنىها را بر اساس تركيب ساختاريشان با استفاده از طيـف بينسى تركيبـى

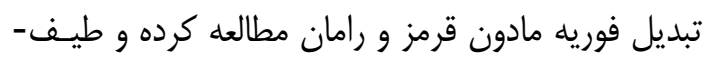

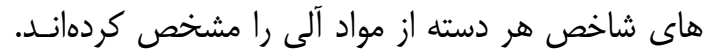

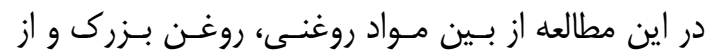

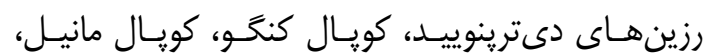
سندروس، كلوفان و تربانتين ونيزى مـورد بررسى قرار

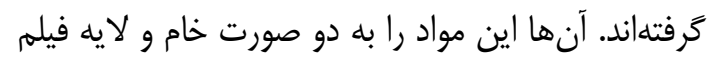
(با حل كردن رزين در اتانول به نسبت يك به دو وزنى إنى وزنى) بر روى لام شيشهاى مورد سنجش قـرار داده و از

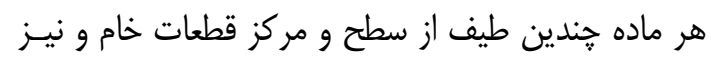
نمونسهــاى فيلم ورنس كرفتنــ (Daher et al., 2010).

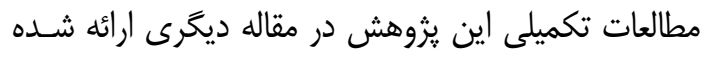

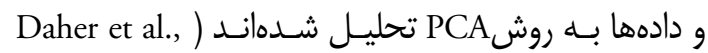
2013). داهر و بلو گورله با استفاده از طيـف بينسى تبـديل

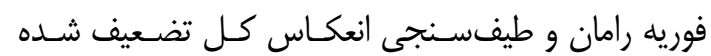

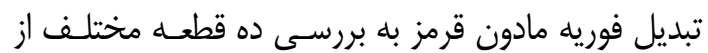

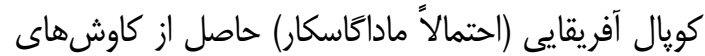

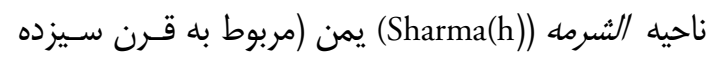
ميلادى) يرداختهاند. ظاهر و رنحَ اين قطعات بـا يكـديخر

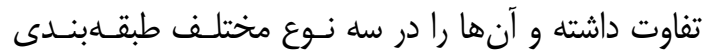
كرده بودند. به همين دليل اين يزوهشكران اين تفاوتهـا

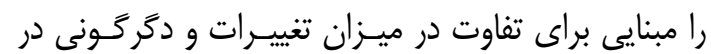

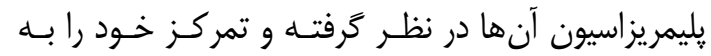

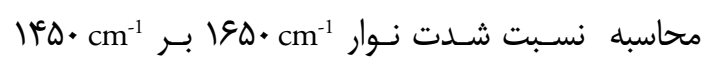
نهادهاند (Daher and Bellot-Gurlet, 2013). اين تسيم در

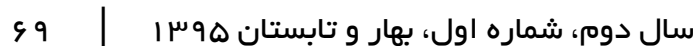

رزين و تغييرات رخ داده در آن طى فر آيند ييرى معرفى و تحليل تردد. بايستى توجه داشت كه شناسايى اين نـوع درع

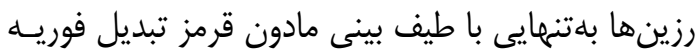

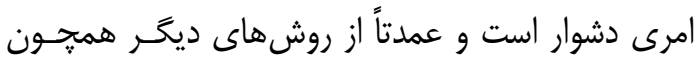

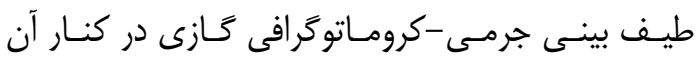

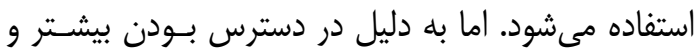

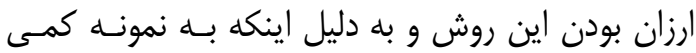

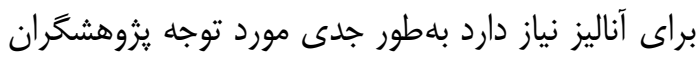

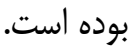

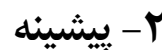

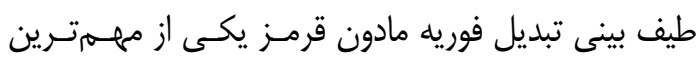
روشهاى شناسايى مواد آلى در آثار تاريخى است. استفاده از اين روش براى شناسايى رزينهاى طبيعى و ورنىها در دراس

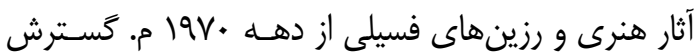
يافـت ( Casadio \& Toniolo, 2001; Echard and (Lavédrine, 2008; Mills and White, 2012 كنار طيف بينى رامان توسعه بيشترى يافته است ( Daher

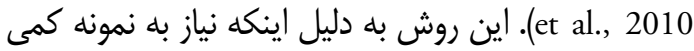

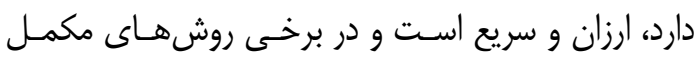

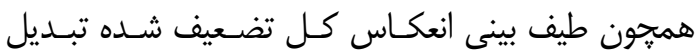

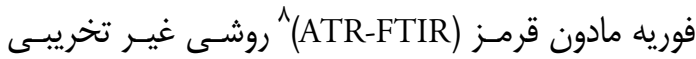

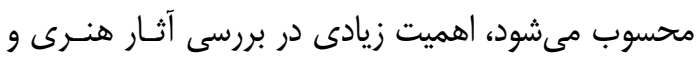
تاريخى يافته است. دريك و همكارانش بله بررسى طيـف مـادون قرمـز

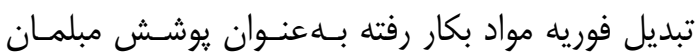
يرداخته و تلاش نمودهاند شاخصههاى ويزه هر رزيـن را

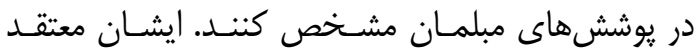

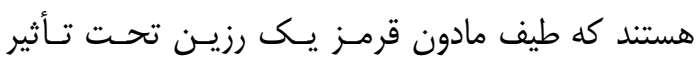

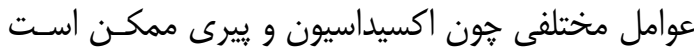
تغيير كند () Derrick et al., 1989; Derrick et al., 2000

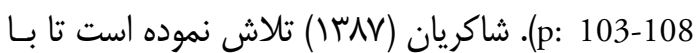
انجام طيفسنجى مادون قرمز تبديل فوريه ساختار ورنى

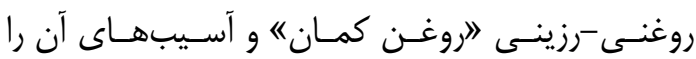

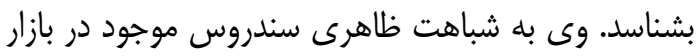

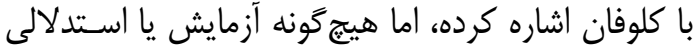
براى اثبات ماهيت ماده مورد نظر خود انجام نداده است. 


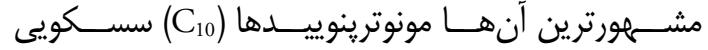

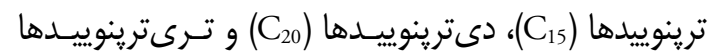

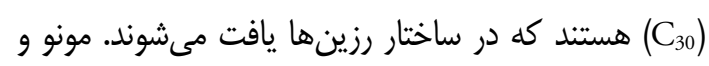

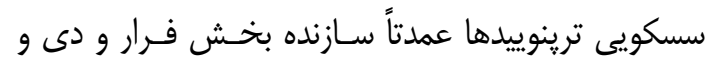
ترى ترينوييدها سازنده بخش غيرفرار رزينها هستند. دى

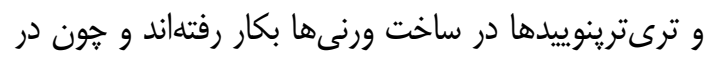

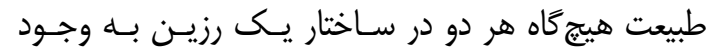

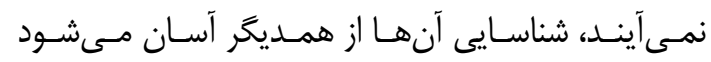
Langenheim, 2003, p: 36; Mills and White, 2012, )

.(p: 95

رزينهاى دىترينوييدى، كه در ساخت انـواع جـلا و لاك بكار رفتهاند، شامل سندروس، انواع كويال، تربـانتين

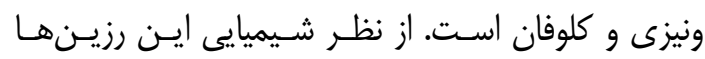
متشكل از اسيدهاى كربوكسيليك حلقوى شناخته شده بـاــا

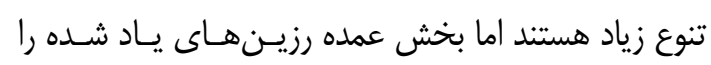
קند ساختار مهمم و شاخص تشكيل مى دهند كه شـامل دو

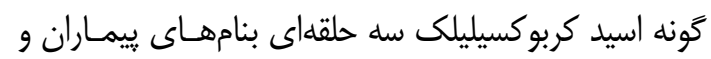

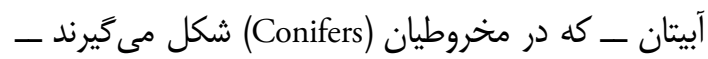

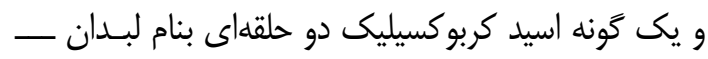
كه در مخروطيـان و نهانـدانكان (Angiosperms) حضـور

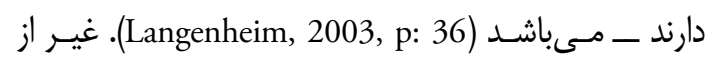

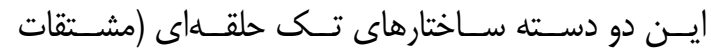

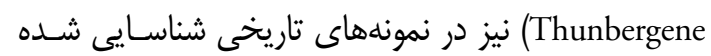

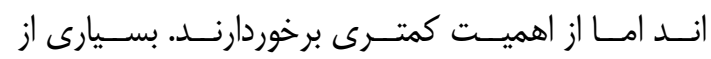

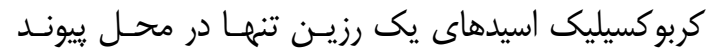

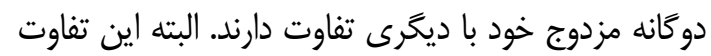
مىتواند عامل تفاوت در ميـزان و سـرعت يليمريزاسـيون

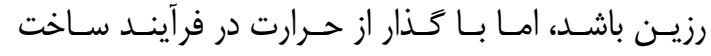
ورنىهاى روغنى - رزينى، اين تركيبات به تركيبات پايسدار

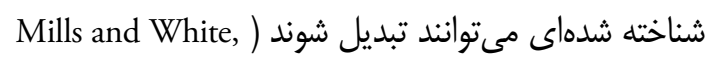

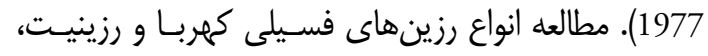

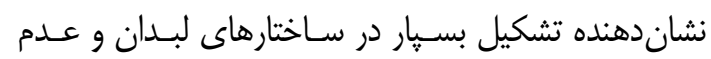

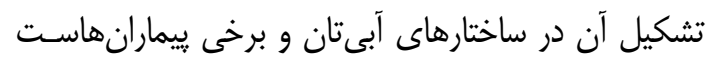
(Anderson and Crelling, 1995, p: xiii) موجب ايجاد تفاوتهاى فيزيكى و شيميايى در رزينهـاى

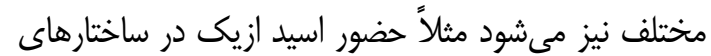

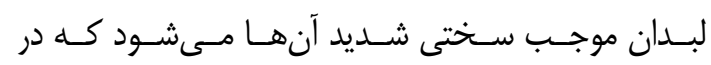

ادامه مطالعات خود بر روى ورنى كلوفـان كروغـن بـزرى

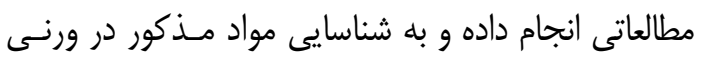
با استفاده از طيف بينى تبديل فوريه مادون قرمز و رامان يرداختهاند (Daher et al., 2014). در اين مطالعه آنهـا

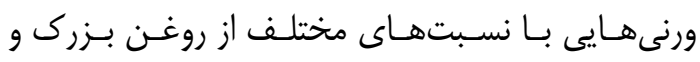

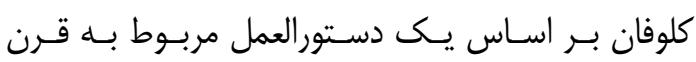

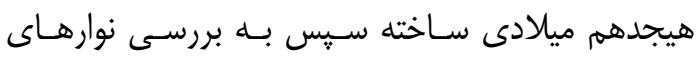

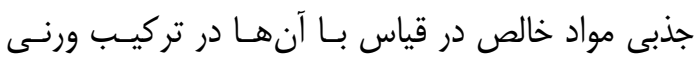

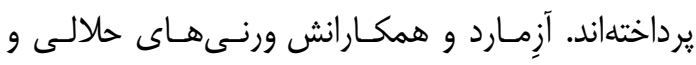

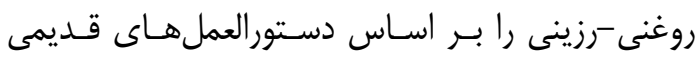

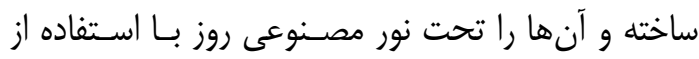

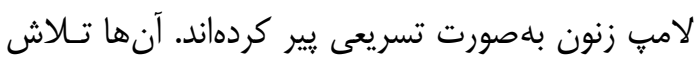
نمودهاند تا نوارهاى جذب شاخص هر رزين طبيعى را در طيف بينى تبديل فوريه مادون قرمز بررسـى و تغييـرات

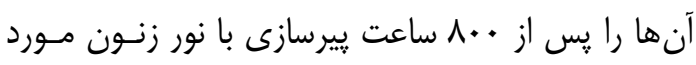

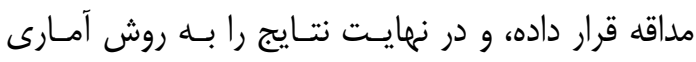

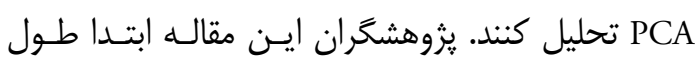

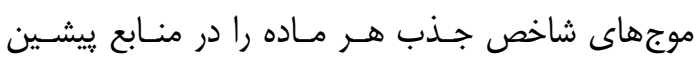
بررسى كرده و سـيس تغييـرات آن را در فرآينـد يِيـرى

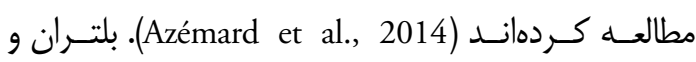
همكارانش به بررسى طيف سـاختار آبيتـانهـاى مختلـف يرداخته و سيس بر اساس آن به شناسايى ايسن سـاختارها

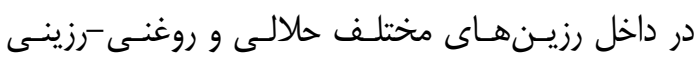

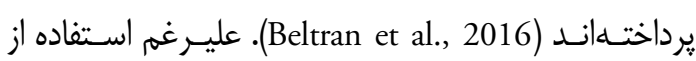
روشهاى دقيـق علمسى، اختلافـاتى در تحليـل و تفسـير

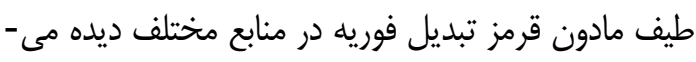

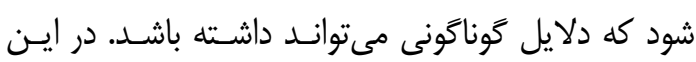
مقاله ضمن بررسى متون علمى مرتبط با موضوع، تحليـل

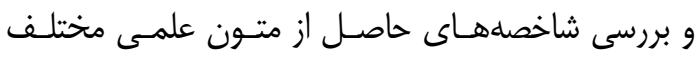
بلددقت مطالعه شده و تلاش شده است اطلاعـات حاصـل

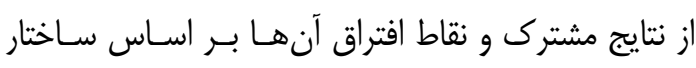
رزينها استخراج و بلصورت تحليلى -مرورى ارائه شود.

\section{ب- ساختار شيميايى دى ترينوييدها}

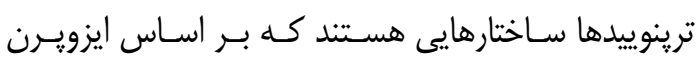
شكل كرفتلهاند (شـكل (). ايسن مـواد (C)

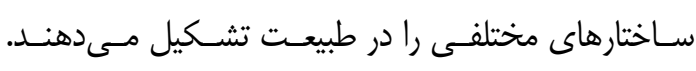

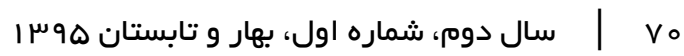




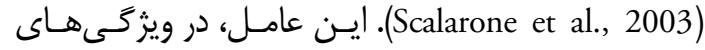

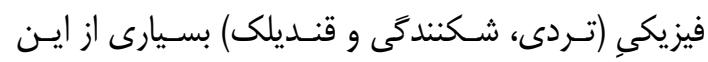

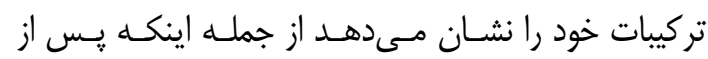
تراوش بلهسرعت سخت مىشوند. به نظر مىرسد يليمـر

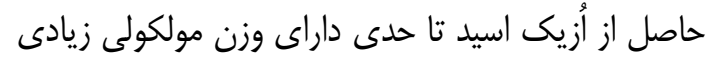
نسبت به يلى كاميونيك اسيد باشد زيرا زمانى كه با حان حلال

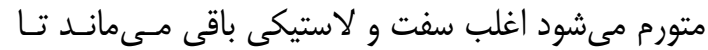

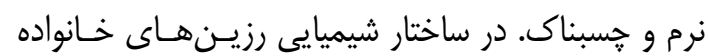
Cupressaceae

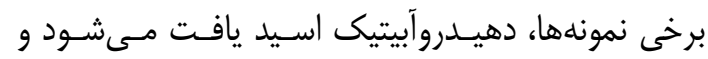
ييماران اسيدها بلهويـزه ســندراكوييماريك اسـيد عمومـاً

$$
\text { بسيار وافرند. }
$$

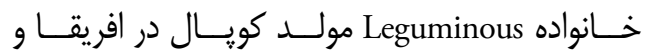

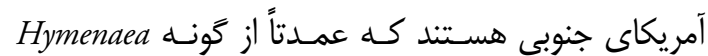

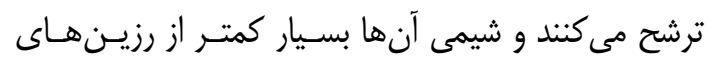

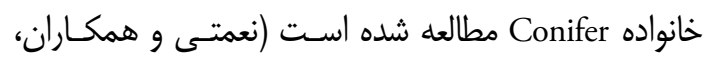

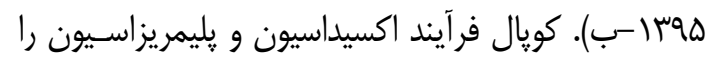

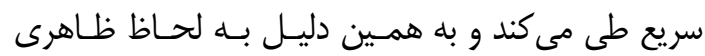

كويالهاى آفريقايى ديده مىشود ( Langenheim, 2003,

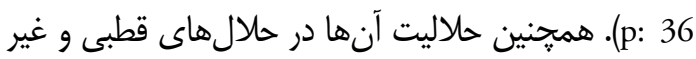
قطبى نيز به ساختار آنها بر مى گَردد.

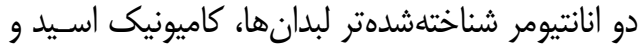

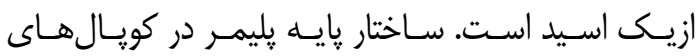

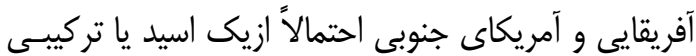

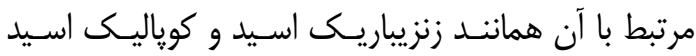

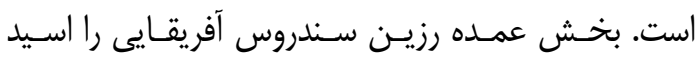

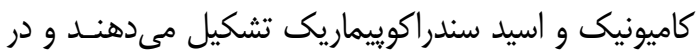

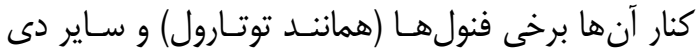

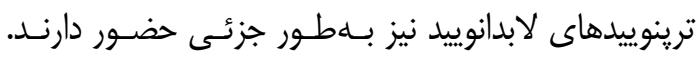

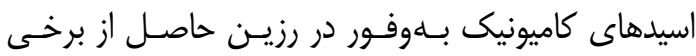

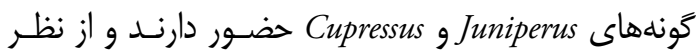
شيميايى تا حدودى شبيه سندروساند. به همـين دليـل در

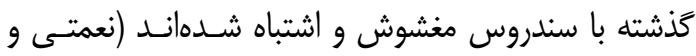

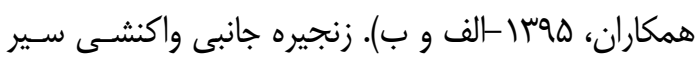

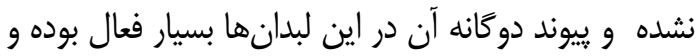

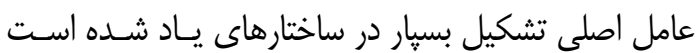

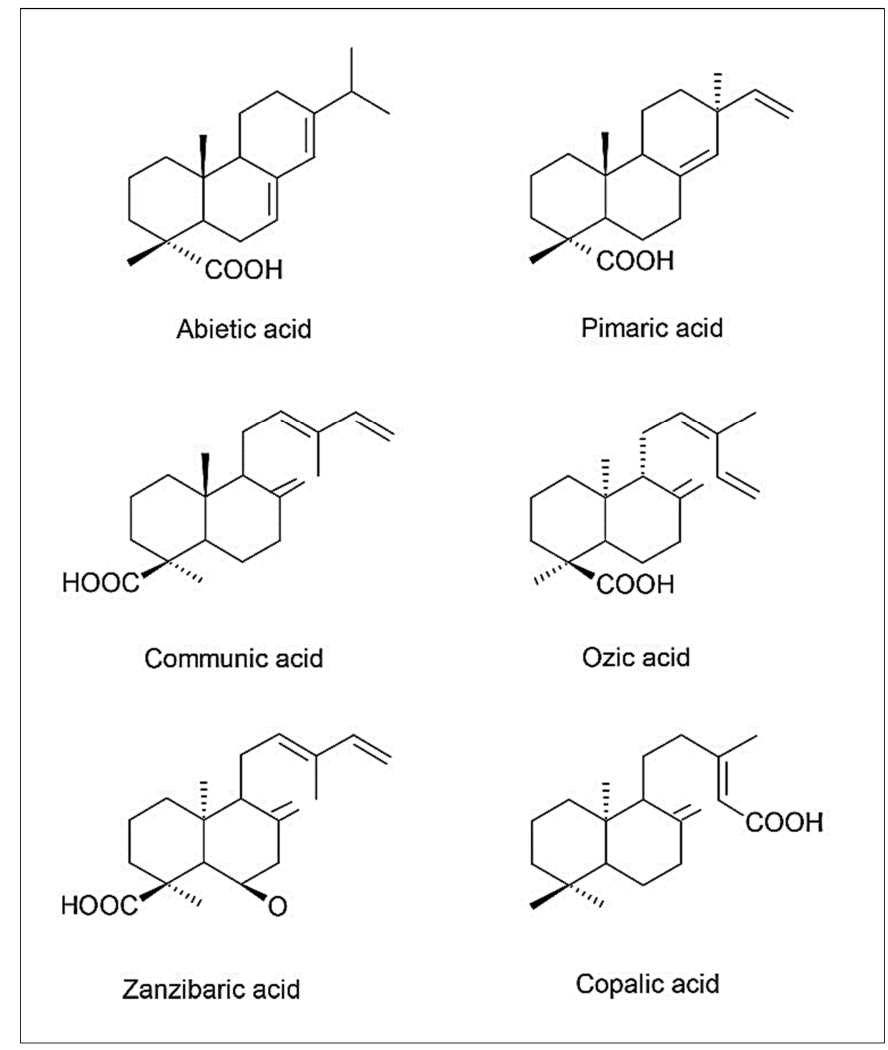

شكل ا: ساختار مولكولى تركيبات سازنده رزينهاى دىترينوييد 
رزينسى يِيجيـدهتر مسى كنــ (Azemard et al., 2014). در

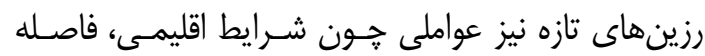

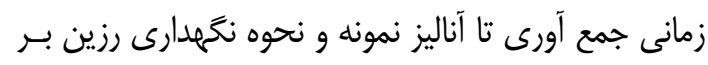

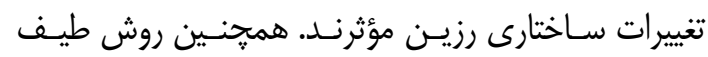

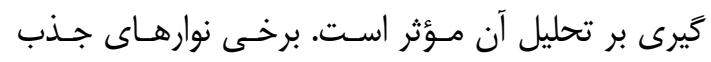

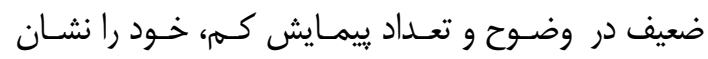

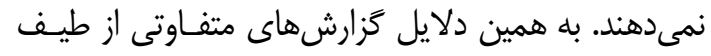

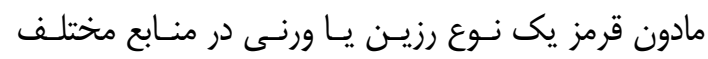
منتشر شده است. طيف مادون قرمز يك رزيـن در جهبـار ناحيـه قابـل

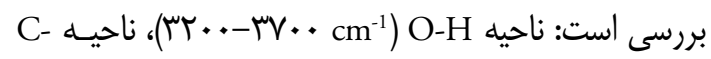

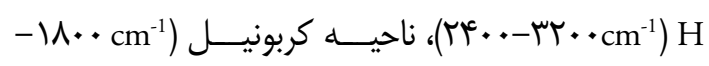

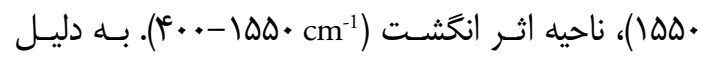
كاربرد رزينهاى دىترينوييدى در روغنها، جهت سـاخت التهات

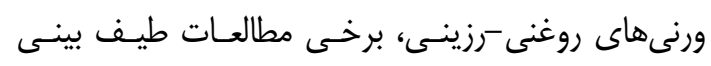

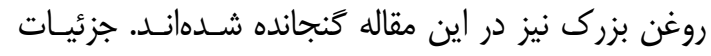

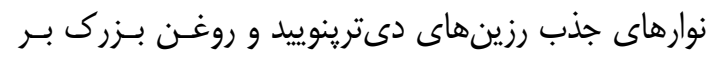

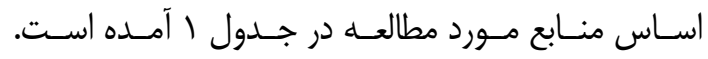
شاخصهاى ويزه شناسايى هر ماده بـا رنـــ خاكسـترى

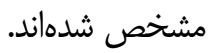
براى شناسايى ساختار يكى ورنى بايستى بــه عوامـل

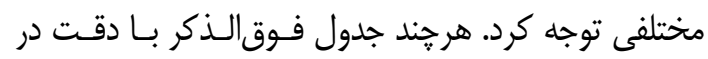
كزارشهاى علمى مختلف تهيه شده اما بايستى توجه كرد

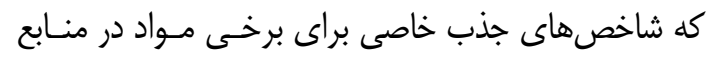

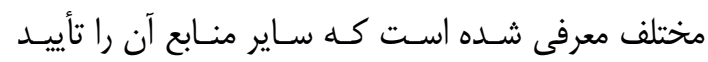

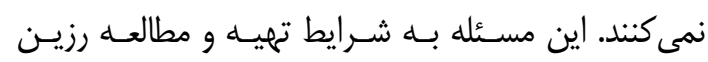

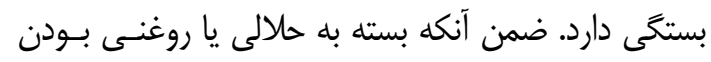

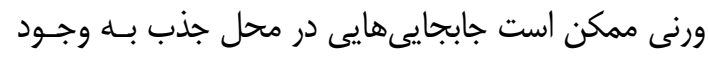

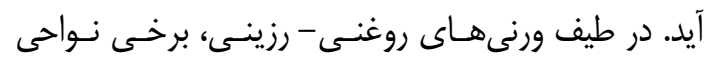

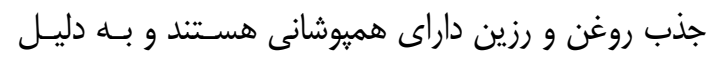

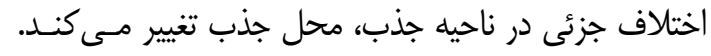

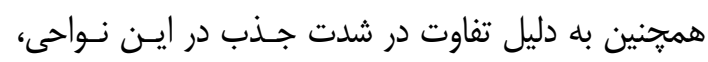

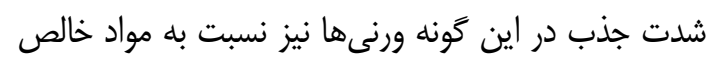
ممكن است تغيير يافته باشد.

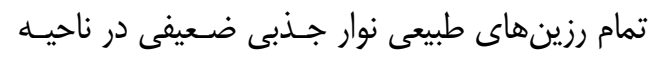

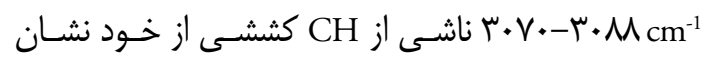

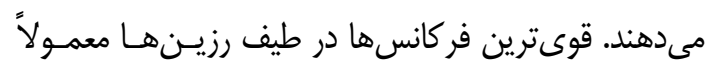

شبيه به كهرباست. بسيارى از كويالها بهواسـطه نرمى و

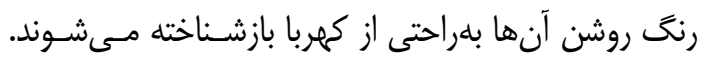

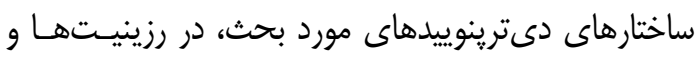
كهرباها نيـز ديـده مسىشـوند ) Anderson and Crelling 1995, p: xiii

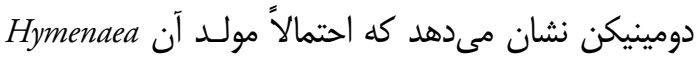
بوده و انواع اشكال دى ترينوييدهاى توليد شــده در آن بـانـا نتايج بررسىهاى ميلز و وايت (Mills and White, 1977)

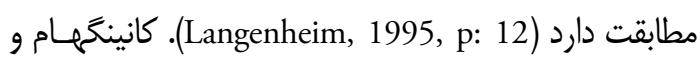

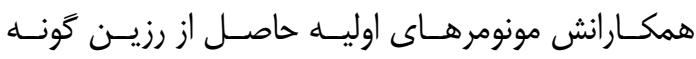
Hymenaea verrucosa

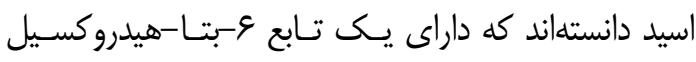

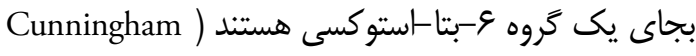

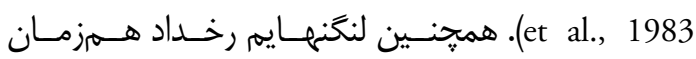

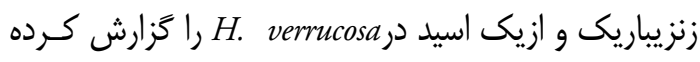

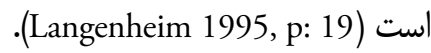
با توجه به اينكه بسيارى از نمونههاى تاريخى فرآيند اكسيداسيون و تشكيل ييوندهاى عرضى را طى مى كنتـد،

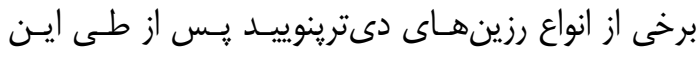

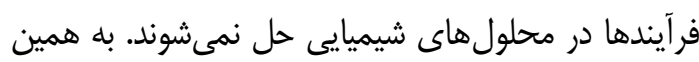

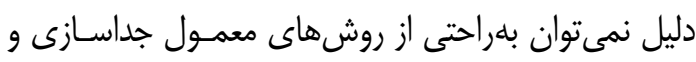

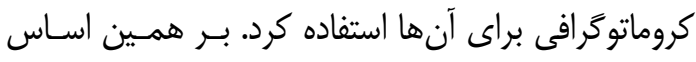

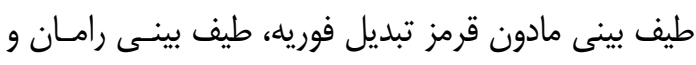

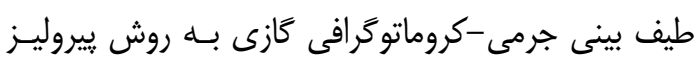
نمونه، بهترين روشهاى شناسايى اين كَنـهـ مـواد در آثـار تاريخى هستند.

\section{f - طيف بينى مادون قرمز رزينهاى دى تىرينوييد}

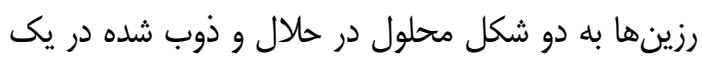
روغن خشكانه براى ساخت ورنىها بكار رفتهاند. بررسى دها دالها

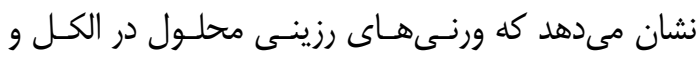

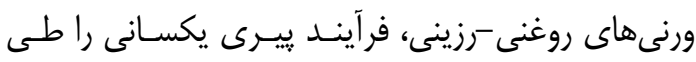

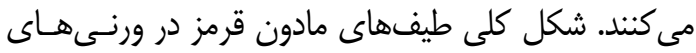

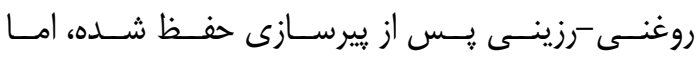

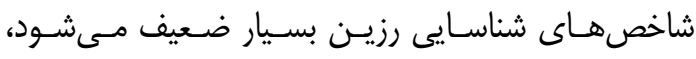

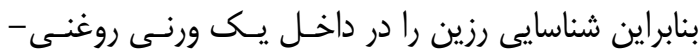

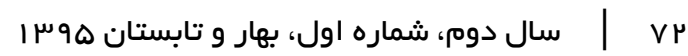


جدول (: شاخصههاى جذب رزينهاى دىترينوييد و روغن بزرك در طيف مادون قرمز تبديل فوريه بر اساس منابع مورد مطالعه

\begin{tabular}{|c|c|c|c|c|c|}
\hline شرح & روغن بزرك & كويال & سندروس & كلوفان & ناحيه \\
\hline & & (w) (qq) & & & \\
\hline & & (m) $\Delta T$. & (m) $\Delta r$. & & \\
\hline \multirow[t]{4}{*}{$\delta \mathrm{CCO}$} & & & (m) $\Delta \Delta S$ & (s) Df. & \\
\hline & & (m) $\Delta \mathcal{R}$ & & $(\mathrm{m}, \mathrm{sh})$ DF $)$ & \\
\hline & & (m) $\Delta \wedge \mu$ & $(\mathrm{m}) \Delta \wedge I$ & & \\
\hline & & (m) $\& \backslash \mathrm{V}$ & & $(\mathrm{w}) 911$ & \\
\hline$\delta$ CCC & & & & (s) $9 \Delta T$ & \\
\hline \multirow[t]{5}{*}{$\mathrm{C}-\mathrm{C}$} & & (m) $9 \vee \Delta$ & 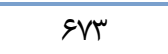 & & \\
\hline & & & $(\mathrm{m}) \subseteq \wedge \Delta$ & & \\
\hline & & (m) 990 & $(\mathrm{~m}) 999$ & & \\
\hline & & & & $V \cdot V$ & \\
\hline & $(w) Y r r$ & & & & \\
\hline \multirow[t]{3}{*}{ ס در دى (COH) } & & (w) $\vee 9 \Delta$ & $(w) \vee 9 r-V \wedge q$ & (w)VQu & \\
\hline & & & שr & שr & \\
\hline & & $\Lambda \Delta$. & $\Lambda \Delta \&$ & & \\
\hline \multirow[t]{3}{*}{ CH خشى در كروه وينيل CH } & & $M 9$ & & & \\
\hline & & & 9.9 & 91. & \\
\hline & $(w)^{q}$ Q. & $(w)^{q} \mathrm{v} \Delta$ & $(w)^{9} \mathrm{vr}$ & $(w)^{q} \mathrm{Q}$. & $\sqrt{2}$ \\
\hline \multirow[t]{2}{*}{ در ساختار ييماران } & & & 1.r. & 1.r. & $\overline{3}$ \\
\hline & & 1. ra & & & \\
\hline \multirow[t]{3}{*}{ Vش كشى v(CO) } & $(s) 11 . r-1.9 \mathrm{~V}$ & & & & \\
\hline & & & & $11 \cdot V$ & \\
\hline & & & & $11 \%$. & \\
\hline$v(\mathrm{CO})$ & & $111 \% 9$ & llaT & $\| \Delta \mid$ & \\
\hline$v(\mathrm{CO})$ & $118 V-1109$ & & & & \\
\hline $\mathrm{C}-\mathrm{O}$ & $(s, b) \| \vee \vee \wedge$ & $(w) I V \wedge$ & $\operatorname{lIV\Lambda (w)}$ & $(w) 11 \wedge$. & \\
\hline $\mathrm{C}-\mathrm{O}$ & $(s, b) \backslash l \vee \wedge$ & $(\mathrm{w})) \backslash \mathrm{VA}$ & $\operatorname{llVN}(\mathrm{w})$ & $(\mathrm{w}) \backslash 1$. & \\
\hline$\delta(\mathrm{COH})$ & & $|r|$. & rוr & $|r|$. & \\
\hline ( $\delta$ خمشى (COH) & (m)ITYL-ITHA & (w)IrrA-IYTL & (w) (w) & (w)וrrq & \\
\hline Oيِ & & & & (w)IYYA & \\
\hline C-O استرها & & ITQQ-ITET & ITDQ-IYGT & & \\
\hline \multirow[t]{4}{*}{ C-O- } & & & & ITVA & \\
\hline & & 每 & ImL & & \\
\hline & & & ITI & & \\
\hline & & IrTq & IrTq & & \\
\hline $\mathrm{CH}_{3}, \mathrm{CH}$ & Irve & & & (m) & \\
\hline $\mathrm{COOH}$ & $(s) 1 F \mid \Lambda$ & $(w) 14$. & $(w) i f i$. & $(\mathrm{w}) 14 \mathrm{f}$ & \\
\hline$-\mathrm{CH}$ & & $(w)$ leca & (w) lefeq & (w) lifto & \\
\hline $\mathrm{CH}_{3} / \mathrm{CH}_{2}, \mathrm{CH}$ & $(s)|+94-|+\varepsilon \mid$ & (w) (w) & (w)וז99 & $(w) i f r$. & \\
\hline آروماتيك C=C & & & If9V & leqs & \\
\hline
\end{tabular}

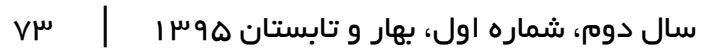




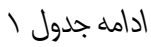

\begin{tabular}{|c|c|c|c|c|c|}
\hline شرح & روغن بزرى & كويال & سندروس & كلوفان & 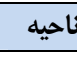 \\
\hline C=C & & & & $|8| 0-|8|$. & \multirow{6}{*}{$\begin{array}{c}2 \\
3 \\
3 \\
3 \\
0 \\
0 \\
0\end{array}$} \\
\hline C=C در وينيل كششى و خمشى & & (m) & $(\mathrm{m}) \backslash 94 \pi$ & (w) (wat & \\
\hline$v(\mathrm{C}=\mathrm{O})$ & & (s) \दq9 & (s) 199$)^{f}$ & (s) $199 \vee$ & \\
\hline اسيدها v(C=O) & (s) $\vee \vee \backslash \Delta$ & $(\mathrm{sh}) \backslash \mathrm{V} \backslash \mathrm{A}$ & (sh) IVIA & (sh) IVIA & \\
\hline استرها v(C=O) & & $(\mathrm{sh}) \mathrm{i} \mathrm{r}^{\circ}$ & $(\mathrm{sh}) \backslash \mathrm{V}^{\mathrm{F}}$. & & \\
\hline استرها v(C=O) & (s) IVD.-IVE. & & & & \\
\hline كربو كسيليك اسيدها OH & & & & $r \Delta H \cdot-r \varepsilon Q$. & \multirow{8}{*}{ 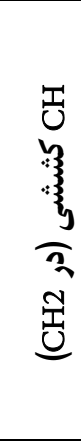 } \\
\hline \multirow[t]{2}{*}{ كششى در وينيل } & & TAMG & TAMG & & \\
\hline & & rAFq & rArq & & \\
\hline $\mathrm{CH}_{2}, \mathrm{~s} v(\mathrm{CH}) \mathrm{s}$ & (s) YAVQ-rADVV & $(s) r \wedge V^{\mu}$ & $(s) r \wedge V^{\mu}$ & $(s / d u) r \Delta \Delta \sigma^{\prime}-r \Lambda V$. & \\
\hline $\mathrm{CH}_{2}, \mathrm{~s} v(\mathrm{CH}) \mathrm{as}$ & (s) rq4人-rqนद & (s) (s) & rqMr (s) & $(s / d u) r a \Delta r-r q \mu$. & \\
\hline در & & rQ⿻५ (s) & $(s)$ raqu & (s) raq4 & \\
\hline كششى C=C & (s) $r \cdots \wedge$ & & & & \\
\hline $\mathrm{CH}_{2}=\mathrm{CRR}^{\prime}, \nu \mathrm{v}(\mathrm{CH})$ & & $(w)^{r} \cdot v q$ & $(w)^{r} \cdot v q$ & $(w)^{r} \cdot v \Delta$ & \\
\hline v(OH) در ورنىهاى كهنه v(OH) & $(s)^{M}{ }^{M} \Delta$. & & & (b) MFA & $\mathrm{O}-\mathrm{H}$ \\
\hline
\end{tabular}

ص: ^^أ). نواحى جذبى شاخص و اختصاصى هــر رزيـن و

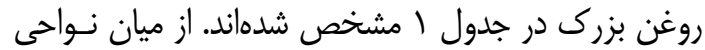
شاخص كلوفان، ناحيه 罗

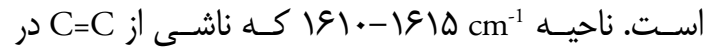

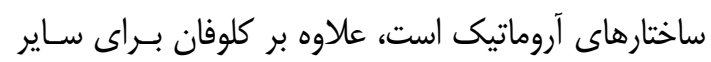

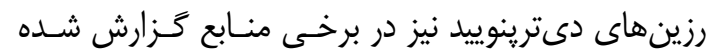

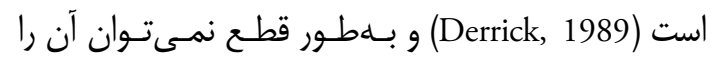
شاخص كلوفان ناميد. همجنين ناحيـه متوسطى براى كلوفان نشان مىدهد كه بـراى روغـن در

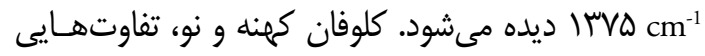

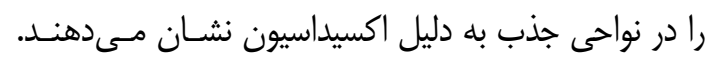
cm شاخصترين اختلاف در آنها جذب كشيده در ناحيه سعبس است كه در كلوفان كهنه قوىتر از كلوفان نو است Daher et al., 2010; Azemard et al., 2014; Cartoni et) cm cil. al., 2003

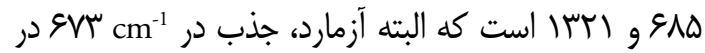

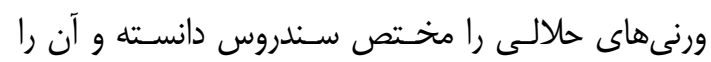
براى كويال گزارش نكرده است (Azemard et al., 2014). جذب در نواحى cm مربـوط بـهـ كربونيـل و هيـدروكربنهـا و در ناحيـهـ و

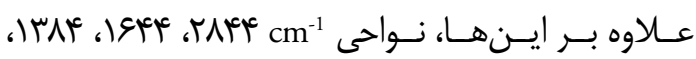

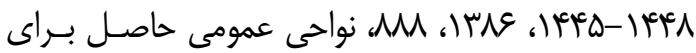

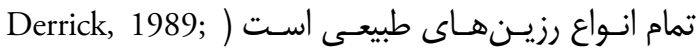
.(Daher et al., 2010; Azemard et al., 2014

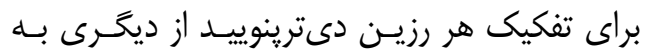
جزئيات بيشترى بايسـى توجـهـ كـرد. بـه دليـل سـاختار

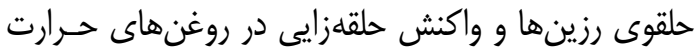

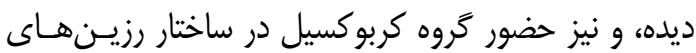

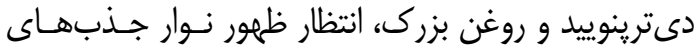

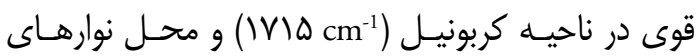
جـذب آروماتيـك ( وجود دارد. نوارهاى جذب آروماتيك بهويزه به دليل تفائ تفاوت در استخلاف بين رزينهاى مشابه حائز اهميت است و درد تعيين فرم استخلاف و در نتيجه تعيين نوع رزيـن كمـى شايانى مىتواند بكند. ظهور نوار جذب متعلق به كربونيـل

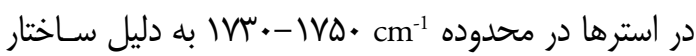

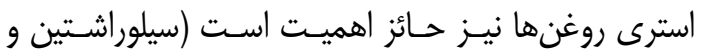

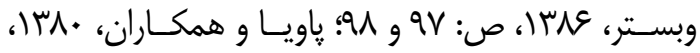


اين امر به ميزان يليمريزاسيون رزين برمى گردد. بـا توجـهـ

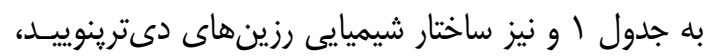

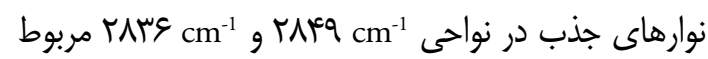

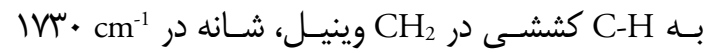

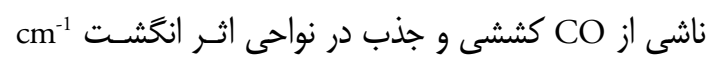

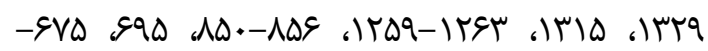
ك

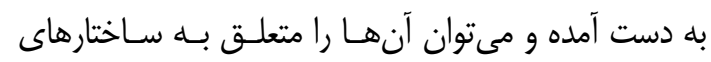

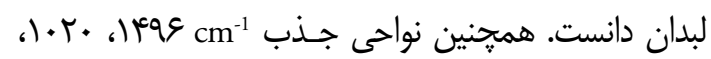

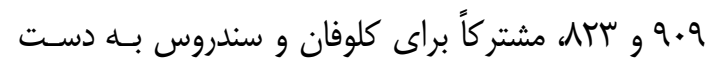

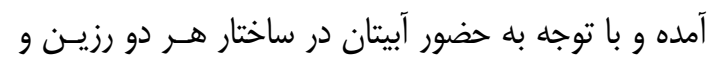

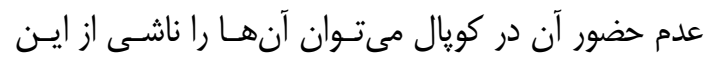

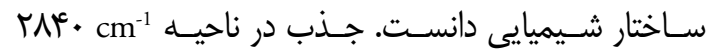

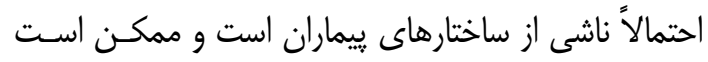
در كلوفان نيز بلهطور ضعيف ديده شود.

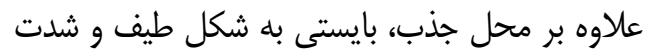

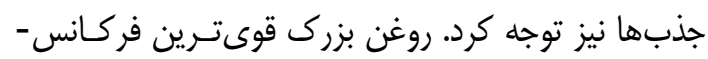
هاى جذب را در نواحى زير نشان مسىدهـد: IVD

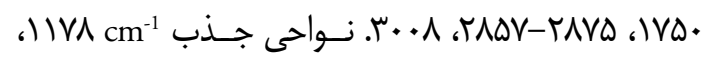

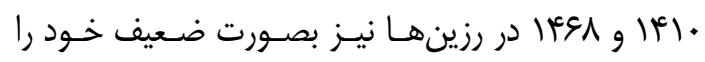

كويال دانستهاند (Derrick, 1989; Prati et al., 2011). بـا توجه به تنوع كويال در دنيا، ناحيه M9 cm بـ بـراي سـاير

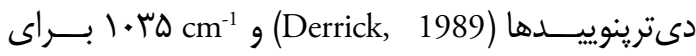
سندروس (Azemard et al., 2014) نيز تزارش شده است.

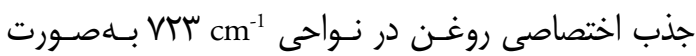

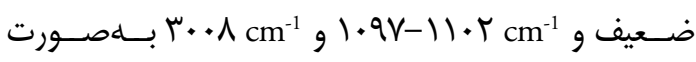

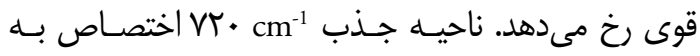
زنجيره طويل

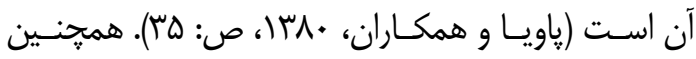

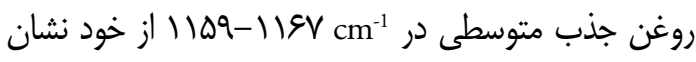

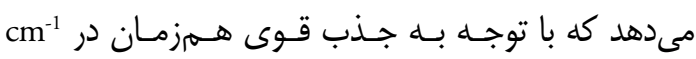

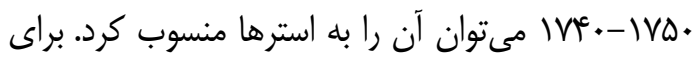

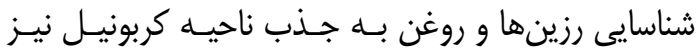

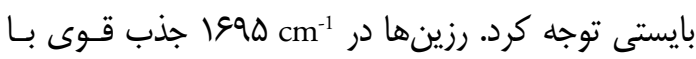

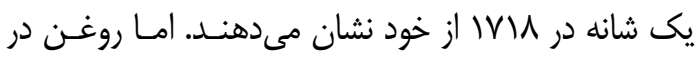

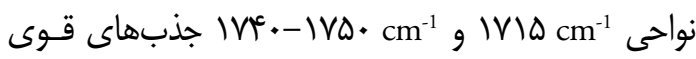

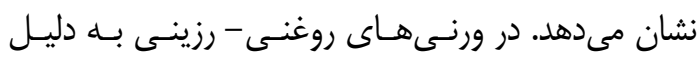

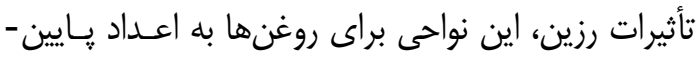

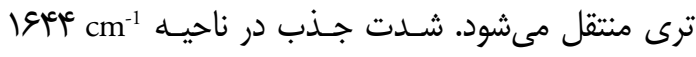

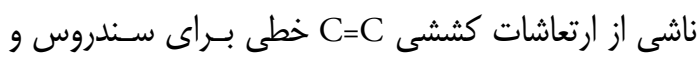

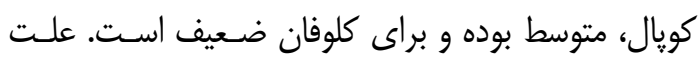

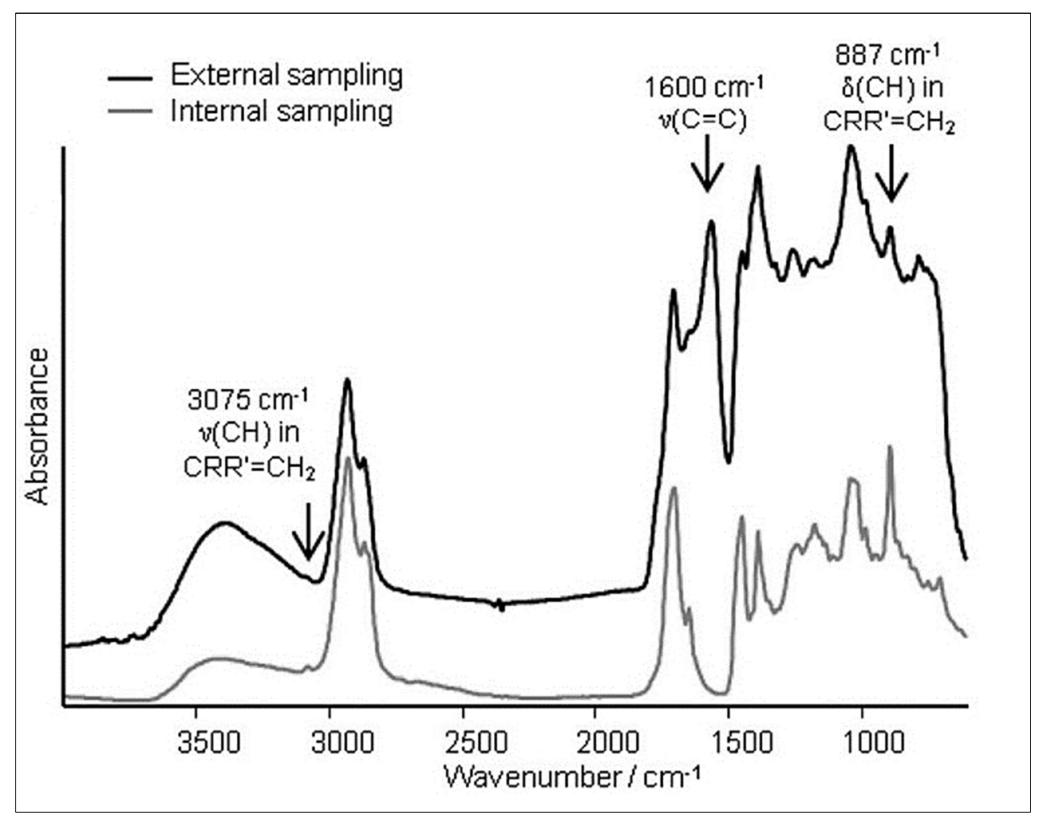

شكل ז: طيف مادون قرمز نمونه سطح (خط سياه) و مغز (خط خاكسترى) كويال قرمز رنخ حاصل از حفارىهاى باستانشناسى الشرهه يمن

(Daher and Bellot Gurlet, 2013) 


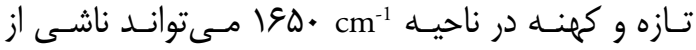

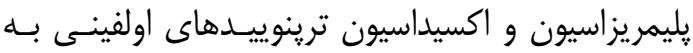
سمت كاهش مقدار C=CH باشد (Daher et al., 2010). بررسى طيفهاى مادون قرمز روغن بزرى طى فرآيند

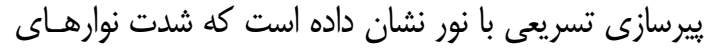

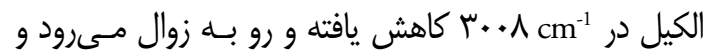

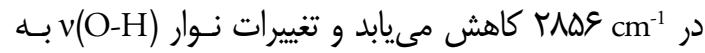

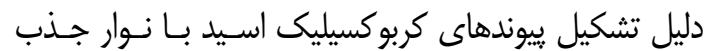
كشيده از

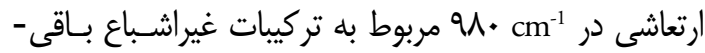
مانده، بِ از سخت شدن فيلم، ضعيف مى شود و ارتعاشات

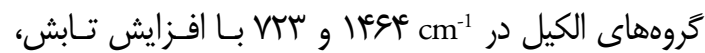
كاهش يافتـهانـــ. تغييـرات در ناحيـه

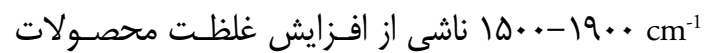

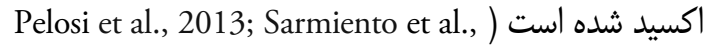
2011; Mallégol et al., 2000

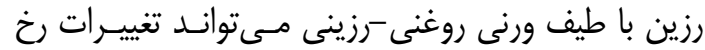

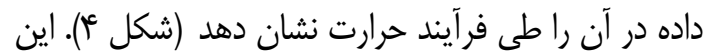

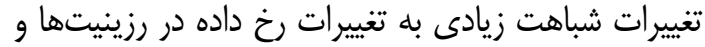

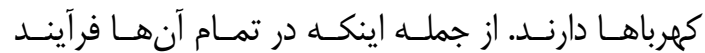

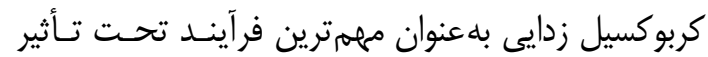

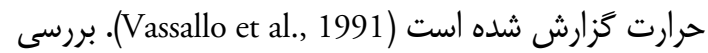
تغييرات شيميايى رخ داده در ساختار رزينيتهاى كائورى نيوزيلند و ترشيارى (Kauri)

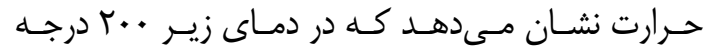

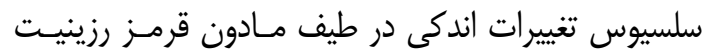

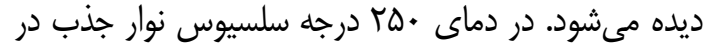

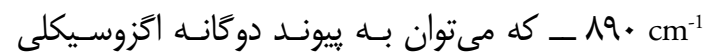

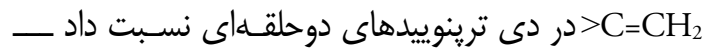

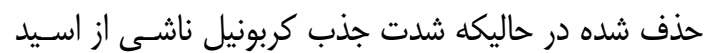

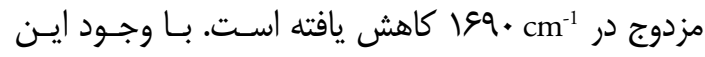

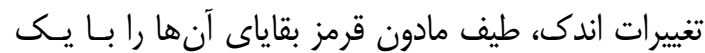

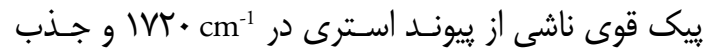

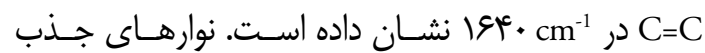

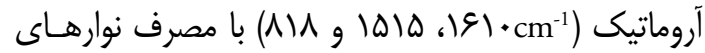

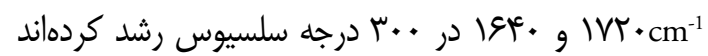

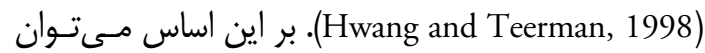
كربوكسيلزدايى اين ساختارها را تحت حرارت، مهمتـرين تغيير ساختارى رزينيتها تحت اعمال حرارت دانست.
نشان مىدهند و اين اختاف شدت مىتواند مبنايى بـراى

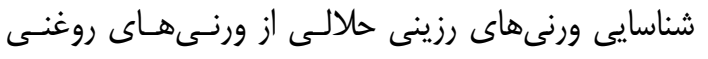

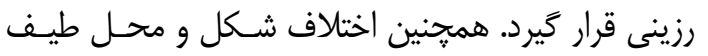

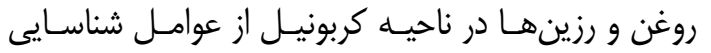
آنهاست. جذب در ناحيه دليل اكسيداسيون ديده مىشود كه قوى و كشيده است و در ورنىهاى تازه ضعيف يا متوسط است.

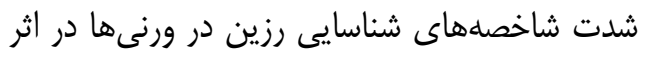
بيرى يا تخريب و يا به علت كاربرد در تركيبى از مـواد، كاهش يافته و يا محل نوار جذبى تغيير مى كنند (شـكل (r

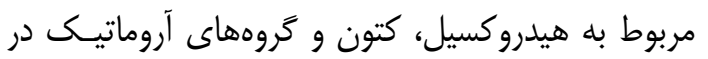
نمونههاى قديمى بيشتر از نمونههاى جديد مى تواند باشد

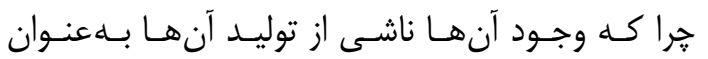

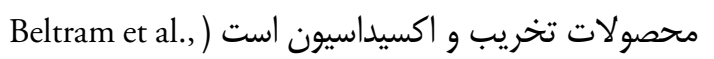

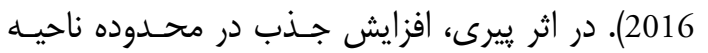
به دليل واكنشهاى اكسيداسيون ديـده مسىشـود.

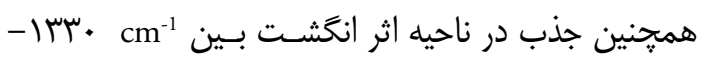

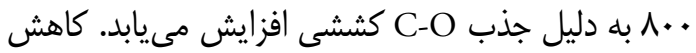

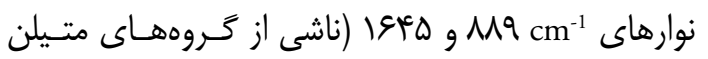

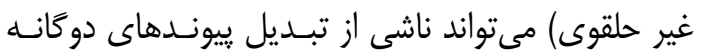

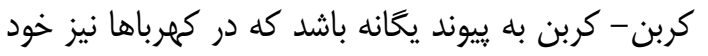
را نشان مىدهد بلهطورى كه اين دو نوار جذبى در كمرباها

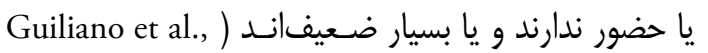

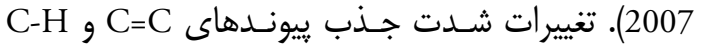

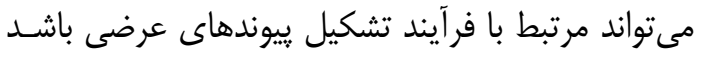

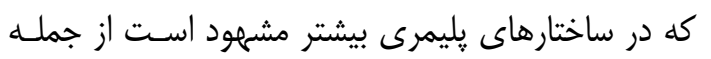

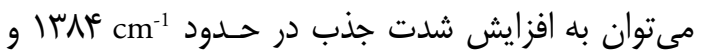
•هأl در ورنى حلالى سندروس اشاره كرد كه مربوط به يبيجش خمشى كروههاى متيل و متيلن است (Scalarone

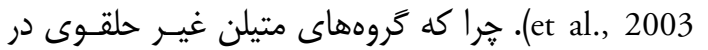

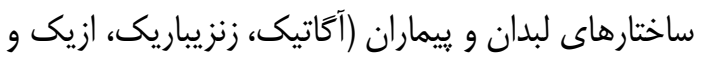
كاميونيك اسيد) حضور دارنــ (Guiliano et al., 2007).

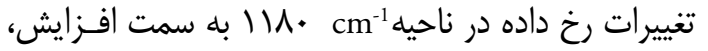
ناشى از C-C-O نيز اثر انخشت مهمى از مراحل تخريب

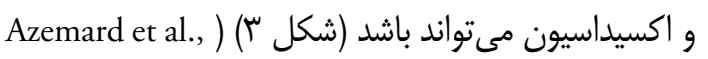
2014; Ciofini et al., 2016 . تفاوت شدت جذب كلوفان 


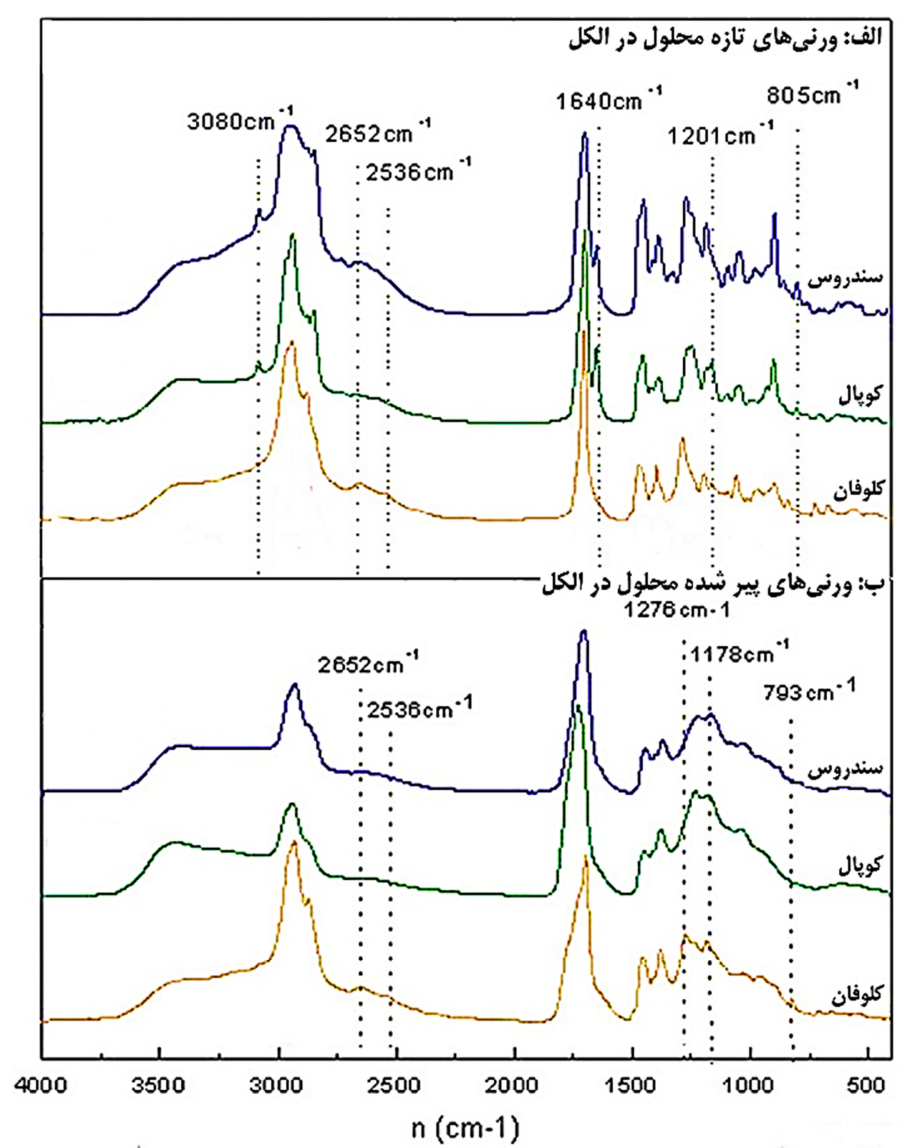

شكل "ا: طيف مادون قرمز تبديل فوريه ورنىهاى حلالى تازه و بيير شده، كاهش شدت ناحيه كربونيل و برخى نوارهاى جذب ناحيه اثر انكشت صِ

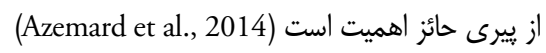

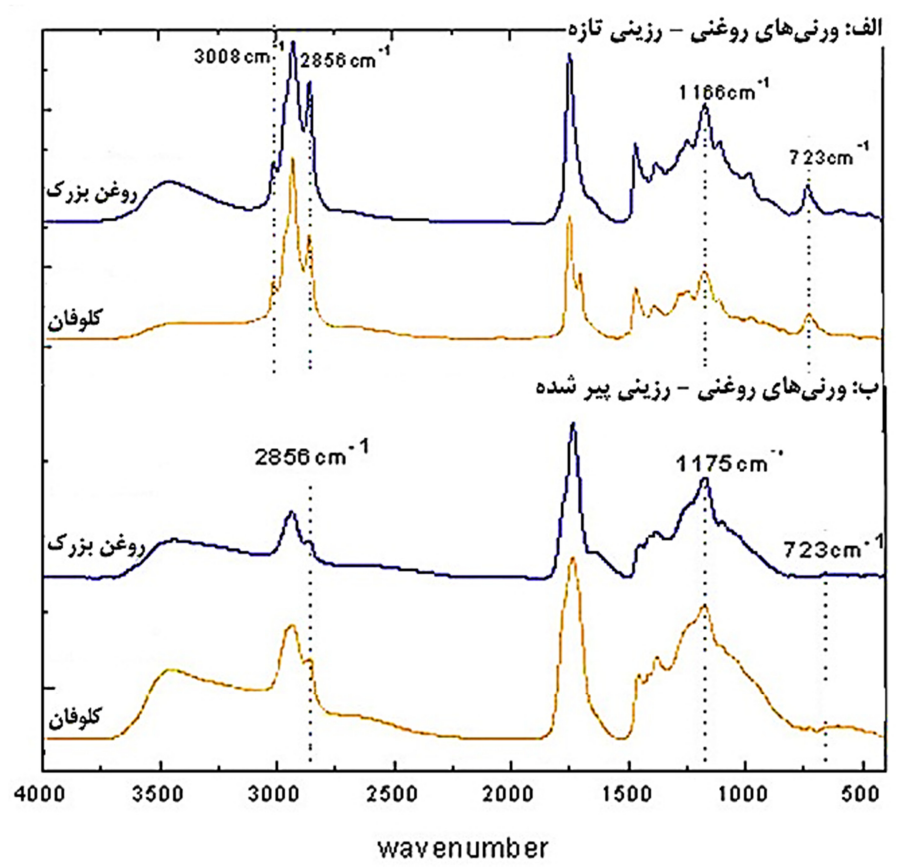

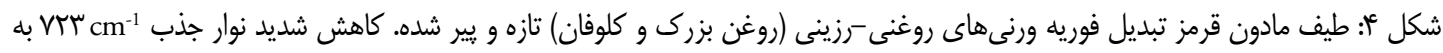

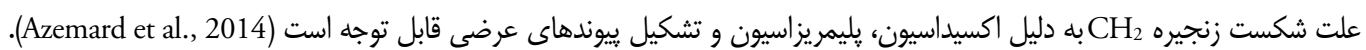

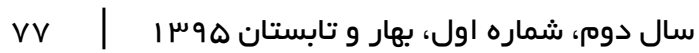


عرضى موجب پديدار شدن نوارهاى جذبى جديد مى شـود.

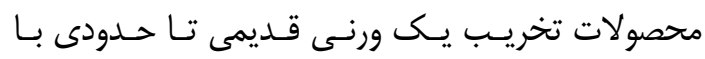

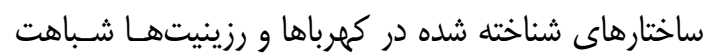

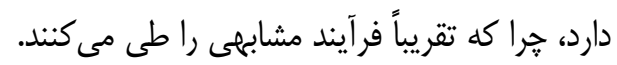

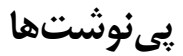

1. Fourier Transform Infrared Spectroscopy

2. Ramman Spectroscopy

3. Mass Spectroscopy

4. Gas Chromatography

5. Pyrolysis

6. Nuclear Magnetic Resonance Spectroscopy ( Vابت شده است كه طولموجهاى كوتاه در محدوده نور فرابنف (UV-C) مىتواند محصولات تخريبى ايجاد كند

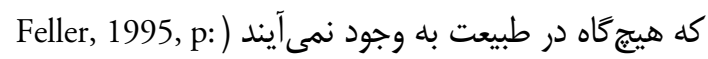

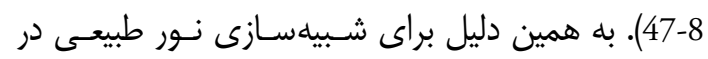

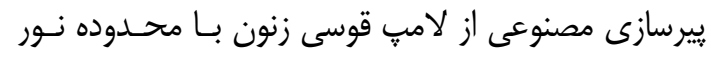

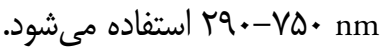

8. Attenuated Total Reflectance- Fourier Transform Infrared Spectroscopy

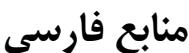

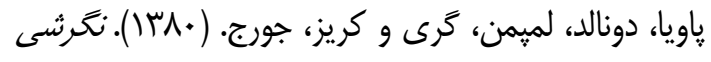

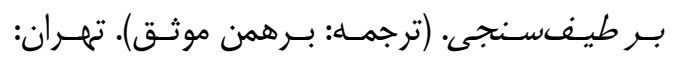

$$
\text { انتشارات علمى و فنى. }
$$

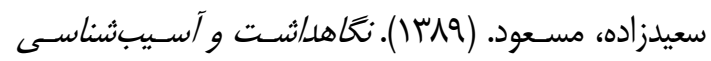

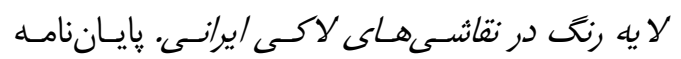
كارشناسى ارشد. دانشكده هنر. دانشخاه هنر اصفهان.

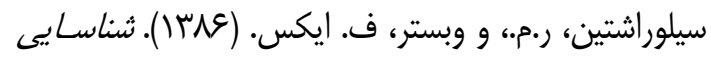

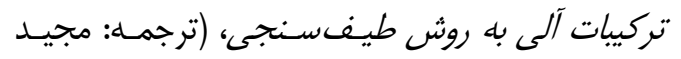

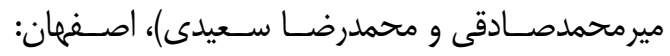

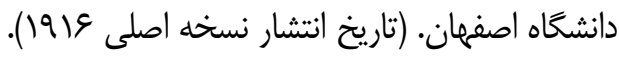

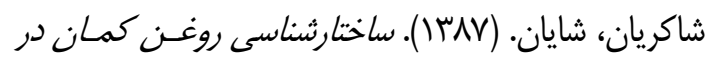
راستاى طرح حفظ و مرمست قلمـان هـاى تـاريخى. يايان نامه كارشناسى ارشد. دانشكده هنر. دانشخاه هنـر

$$
\text { اصفهان. }
$$

محتشه، عادله. (1) (1). فنشناسى، آسيبشناسى و طـرح

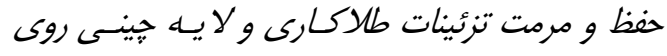
سنك در دورمى قاجـار (مطالعهىى مـوردى: تزئينـات
واكنشهاى شيميايى كه منجر به تغيير در رزينيتها

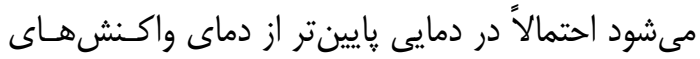

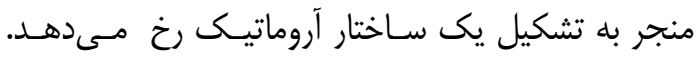
شدت نوارهاى جذب كروههاى كربو كسيل ( (IVT.

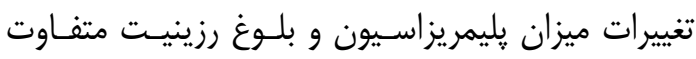
cm است. كاهش شدت جذب گروه كربو كسيل در ناحيه

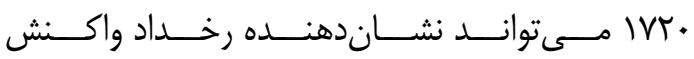

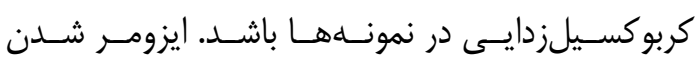

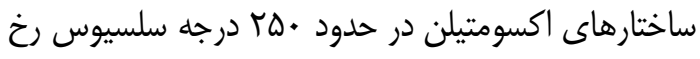

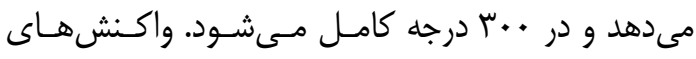

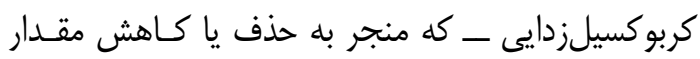
كروه عاملى كربو كسيل شده و منجر به تشكيل كروههاى

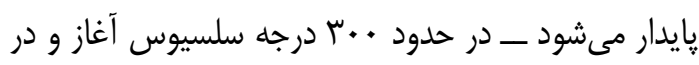

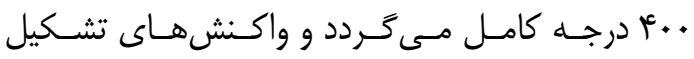

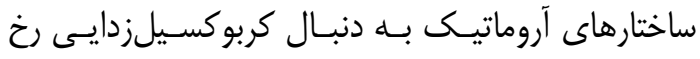

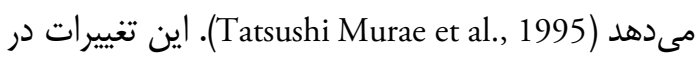

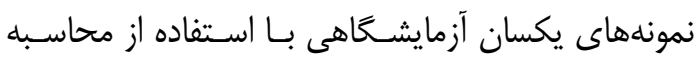

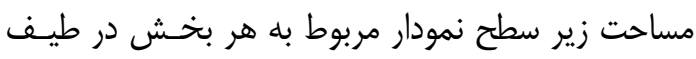

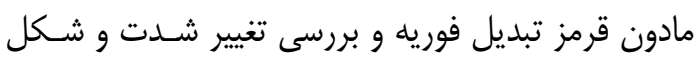
نوار جذب قابل محاسبه و مطالعه است.

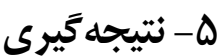

تفاوت در ساختار شيميايى رزينهاى دى دئرينوي

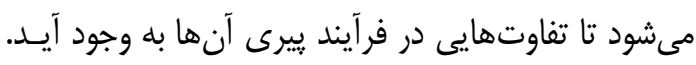

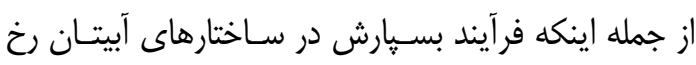

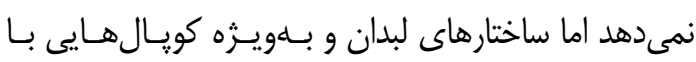

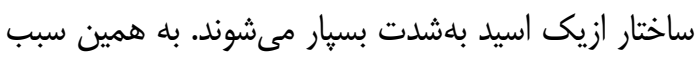

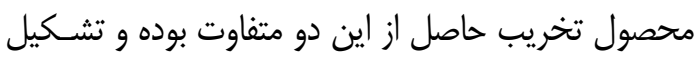

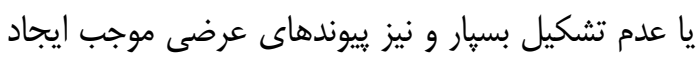

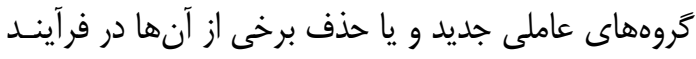

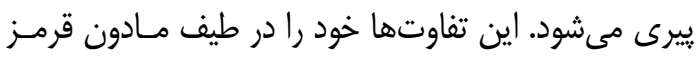

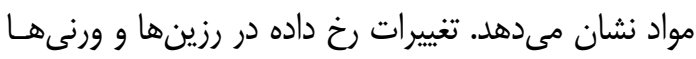

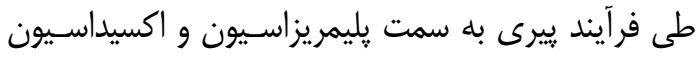

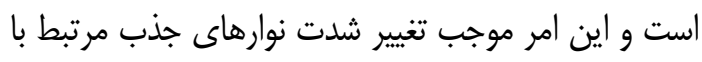

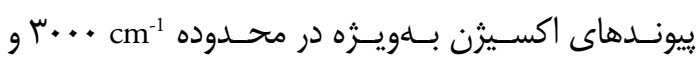

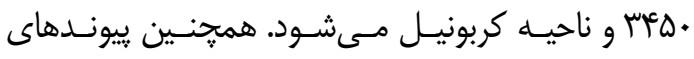




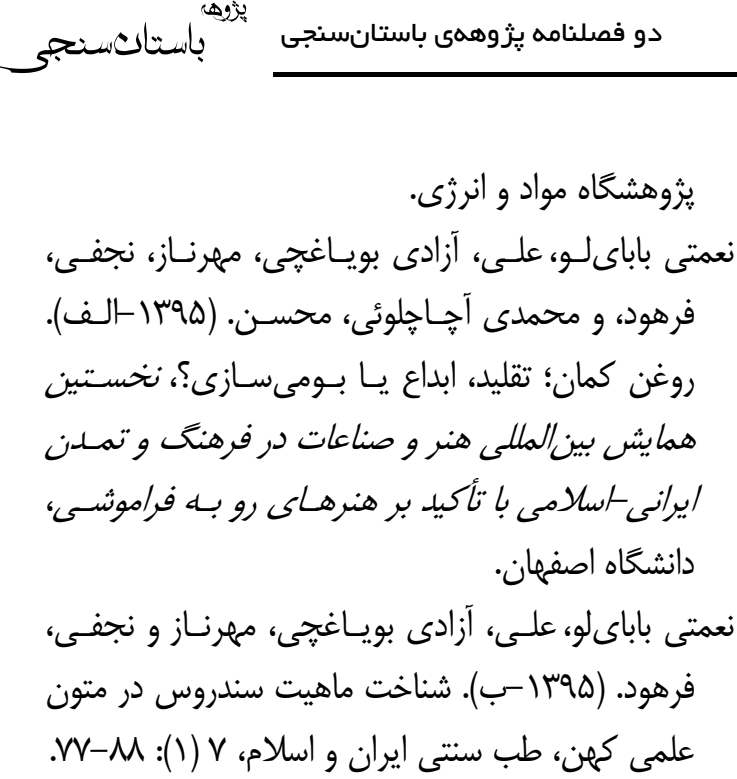

منابع لاتين

Anderson, K. B. \& Crelling, J. C. (Editors) (1995). Amber, resinite, and fossil resins (Developed from a symposium sponsored by the Division of Geochemistry, Inc., at the 208th National Meeting of the American Chemical Society, Washington, DC, August 21-25, 1994). Washington DC: American Chemical Society.

Anderson, K. \& Crelling, J. (1995). Introduction. In Amber, resinite, and fossil resins. pp. xi-xvii. Washington DC: American chemistry society.

Azémard, C., Vieillescazes, C., \& Ménager, M. (2014). Effect of photodegradation on the identification of natural varnishes by FT-IR spectroscopy. Microchemical Journal, 112, 137149.

Beltran, V., Salvadó, N., Butí, S., \& Pradell, T. (2016). Ageing of resin from Pinus species assessed by infrared spectroscopy. Analytical and bioanalytical chemistry, 408(15), 4073-4082.

Cartoni, G., Russo, M. V., Spinelli, F., \& Talarico, F. (2003). Characterisation of fresh and aged terpenic resins by micro-FTIR and GC-MS analyses of varnishes in XVI-XVII centuries paintings. Annali di chimica, 93(11), 849-861.

Casadio, F., \& Toniolo, L. (2001). The analysis of polychrome works of art: 40 years of infrared spectroscopic investigations. Journal of Cultural Heritage, 2(1), 71-78.

Ciofini, D., Striova, J., Camaiti, M., \& Siano, S. (2016). Photo-oxidative kinetics of solvent and oil-based terpenoid varnishes. Polymer Degradation and Stability, 123, 47-61.

Cunningham, A., Gay, I. D., Oehlschlager, A. \& Langenheim, J. H. (1983). 13 C NMR and IR analyses of structure, aging and botanical origin of Dominican and Mexican ambers. Phytochemistry., 22(4), 965-968.

Daher, C. \& Bellot-Gurlet, L. (2013). Nondestructive characterization of archaeological

$$
\begin{aligned}
& \text { طلاكسـارى و لا يــه جرينــى روى ســنَ موجــود در }
\end{aligned}
$$

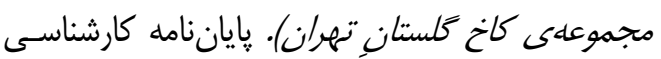

$$
\begin{aligned}
& \text { ارشد. دانشكده هنر. دانشعاه هنر اصفهان. }
\end{aligned}
$$

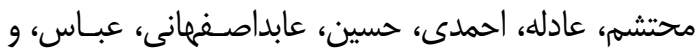

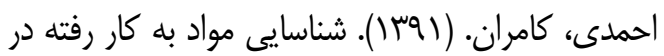

$$
\begin{aligned}
& \text { اجراى تزيينات طلاكارى روى سنَ (مطالعه مـوردى: }
\end{aligned}
$$

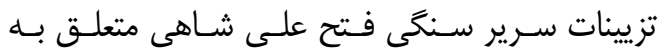

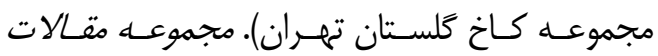

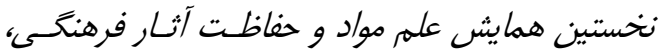

$$
\begin{aligned}
& \text { تـــاريخى ( }
\end{aligned}
$$

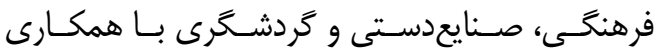

resins: seeking alteration criteria through vibrational signatures. Analytical Methods., 5(23), 6583-6591.

Daher, C., Bellot-Gurlet, L., Le Hô, A.-S., Paris, C. \& Regert, M. (2013). Advanced discriminating criteria for natural organic substances of Cultural Heritage interest: Spectral decomposition and multivariate analyses of FTRaman and FT-IR signatures. Talanta., 115, 540-547.

Daher, C., Paris, C., Le Hô, A., Bellot-Gurlet, L. \& Échard, J. (2010). A joint use of Raman and infrared spectroscopies for the identification of natural organic media used in ancient varnishes. Journal of Raman Spectroscopy., 41(11), 1494-1499.

Daher, C., Pimenta, V. \& Bellot-Gurlet, L. (2014). Towards a non-invasive quantitative analysis of the organic components in museum objects varnishes by vibrational spectroscopies: Methodological approach. Talanta., 129, 336345.

Daher, C., Drieu, L., Bellot-Gurlet, L., Percot, A., Paris, C., \& Le Hô, A. S. (2014). Combined approach of FT-Raman, SERS and IR microATR spectroscopies to enlighten ancient technologies of painted and varnished works of art. Journal of Raman Spectroscopy, 45(11-12), 1207-1214.

Derrick, M. (1989). Fourier transform infrared spectral analysis of natural resins used in furniture finishes. Journal of the American Institute for Conservation, 28(1), 43-56.

Derrick, M. R., Stulik, D., \& Landry, J. M. (2000). Infrared spectroscopy in conservation science. Getty Publications.

Echard, J.-P. \& Lavédrine, B. (2008). Review on the characterisation of ancient stringed musical instruments varnishes and implementation of an analytical strategy. Journal of Cultural Heritage., 9(4), 420-429 
Feller, R. L. (1995). Accelerated aging: photochemical and thermal aspects. Getty Publications.

Hwang, R. \& Teerman, S. (1988). Hydrocarbon characterization of resinite. Energy \& fuels., 2(2), 170-175

Langenheim, J. H. (2003). Plant resins: chemistry, evolution, ecology, and ethnobotany. Portland/Cambridge: Timber Press.

Langenheim, J. H. (1995). Biology of amberproducing trees: focus on case studies of Hymenaea and Agathis.

Mallégol, J., Gardette, J.-L. \& Lemaire, J. (2000). Long-term behavior of oil-based varnishes and paints. Photo-and thermooxidation of cured linseed oil. Journal of the American Oil Chemists' Society., 77(3), 257-263.

Mills, J. S. \& White, R. (1977). Natural resins of art and archaeology their sources, chemistry, and identification. Studies in Conservation., 22(1), 1231.

Mills, J. \& White, R. (2012). Organic Chemistry of Museum Objects. Taylor \& Francis.

Murae, T., Shimokawa, S. \& Aihara, A. (1995). Pyrolytic and spectroscopic studies of the diagenetic alteration of resinites. In Amber, resinite, and fossil resins. Washington DC: American Chemical Society

Pelosi, C., Falletta, G., De Dominicis, B., \& Baraldi, P. (2013). The painted silk panels of Palazzo
Barberini at Rome. The scientific investigation and preservation challenge. Procedia Chemistry, 8 , 248-257.

Prati, S., Sciutto, G., Mazzeo, R., Torri, C., \& Fabbri, D. (2011). Application of ATR-farinfrared spectroscopy to the analysis of natural resins. Analytical and bioanalytical chemistry, 399(9), 3081-3091.

Ribechini, E. (2009). Direct mass spectrometric techniques: versatile tools to characterise resinous materials. Organic mass spectrometry in art and archaeology. New York: Wiley., 77-95.

Sarmiento, A., Pérez-Alonso, M., Olivares, M., Castro, K., Martínez-Arkarazo, I., Fernández, L. A., \& Madariaga, J. M. (2011). Classification and identification of organic binding media in artworks by means of Fourier transform infrared spectroscopy and principal component analysis. Analytical and bioanalytical chemistry, 399(10), 3601-3611.

Scalarone, D., Lazzari, M., \& Chiantore, O. (2003). Ageing behaviour and analytical pyrolysis characterisation of diterpenic resins used as art materials: Manila copal and sandarac. Journal of analytical and applied pyrolysis, 68, 115-136.

Vassallo, A. M., Liu, Y. L., Pang, L. S. K., \& Wilson, M. A. (1991). Infrared spectroscopy of coal maceral concentrates at elevated temperatures. Fuel, 70(5), 635-639. 